\title{
Toward a structural understanding of Clostridium difficile toxins $A$ and $B$
}

\author{
Rory N. Pruitt and D. Borden Lacy* \\ Department of Pathology, Microbiology and Immunology, Vanderbilt University School of Medicine, Nashville, TN, USA
}

\section{Edited by:}

Jimmy Ballard, University of

Oklahoma Health Sciences Center,

USA

\section{Reviewed by:}

Rita Tamayo, University of North

Carolina at Chapel Hill, USA

Stephanie M. Seveau, The Ohio

State University, USA

*Correspondence:

D. Borden Lacy, Department of

Pathology, Microbiology and

Immunology, Vanderbilt University

School of Medicine, A-5301 Medical

Center North, 1161 21st Avenue

South, Nashville, TN 37232-2363,

USA.

e-mail: borden.lacy@vanderbilt.edu
Clostridium difficile is a toxin-producing bacterium that is a frequent cause of hospital-acquired and antibiotic-associated diarrhea. The incidence, severity, and costs associated with $C$. difficile associated disease are substantial and increasing, making C. difficile a significant public health concern. The two primary toxins, TcdA and TcdB, disrupt host cell function by inactivating small GTPases that regulate the actin cytoskeleton. This review will discuss the role of these two toxins in pathogenesis and the structural and molecular mechanisms by which they intoxicate cells. A focus will be placed on recent publications highlighting mechanistic similarities and differences between TcdA, $\mathrm{TcdB}$, and different TcdB variants.

Keywords: $C$. difficile, bacterial toxin, receptor-binding, pore formation, autoprocessing, glucosyltransferase

\section{CLOSTRIDIUM DIFFICILE ASSOCIATED DISEASE}

Clostridium difficile was first described in 1935 by Ivan Hall and Elizabeth O'Toole (Hall and O'Toole, 1935). The researchers discovered the bacteria while investigating the bacterial colonization of the intestinal tracts of normal infants during the first 10 days following birth. Hall and O'Toole found that C. difficile was toxic toward animals and produced secreted toxic factor(s). Nevertheless, the bacteria had been isolated from normal infants, and there was no indication that the presence of the bacteria had any deleterious effects on the newborns. Thus, for the next four decades $C$. difficile remained a little known bacterium that was considered a part of the normal intestinal flora of infants.

C. difficile's rise from obscurity began in the 1970s when it was found to be the primary cause of pseudomembranous colitis (PMC). PMC is a severe condition characterized by inflammation of the colon with the formation of plaques, or pseudomembranes, composed of fibrin, mucin, necrotic epithelial cells, and neutrophils. (Lyerly et al., 1988; Kelly et al., 1994). PMC had been described as early as 1893 , but the causative agent was undefined for decades (Finney, 1893). Following the development and use of broad-spectrum antibiotics, the number of PMC cases increased dramatically (Lyerly et al., 1988). An especially large number of reported cases occurred in the 1970s following introduction of clindamycin (Cohen et al., 1973; Kabins and Spira, 1975). With this rise in incidence, the search for the cause of PMC intensified, and by the late 1970s there was strong evidence from a number of groups that $C$. difficile was the causative agent (Lyerly et al., 1988). Moreover, the toxic secreted components that Hall and O'Toole noted in filtrates from C. difficile cultures were implicated in causing PMC. The toxic components were identified as two proteins, toxin $\mathrm{A}(\mathrm{TcdA})$ and toxin B (TcdB).

Although the pathogenicity of $C$. difficile toward humans was first discovered in relation to its ability to cause PMC, it is now known that the manifestations of $C$. difficile infection can range from asymptomatic carriage, to mild diarrhea, to life-threatening conditions such as PMC and toxic megacolon. Collectively, the manifestations of disease caused by $C$. difficile are referred to as C. difficile associated disease (CDAD). Sohn et al. have estimated that there are 7 CDAD case patients per 1,000 admissions in acute care hospitals (Sohn et al., 2005). It should be noted, however, that $C$. difficile burden varies dramatically by geographic region, between institutions, and even between wards of the same hospital (Lyerly et al., 1988; Bartlett, 1994; Sohn et al., 2005; McDonald et al., 2007). Total costs of $C$. difficile to the US health care system are thought to exceed $\$ 3$ billion per year (Kyne et al., 2002; Brazier, 2008).

Between the late 1990s and mid 2000s there was a dramatic increase in the number of cases of CDAD. Rates of CDAD more than doubled in many localities (Kelly and LaMont, 2008). According to death certificate data, $C$. difficile related deaths in the US rose from 5.7 deaths per million in the population in 1999 to 23.7 in 2004 (Redelings et al., 2007). This vast upsurge in CDAD has been primarily attributed to the emergence of more virulent strains categorized as North American pulsotype 1/PCR-ribotype 027 (NAP1/027). NAP1/027 strains have been reported to have higher production of TcdA and TcdB (Warny et al., 2005), a more cytopathic form of TcdB (Stabler et al., 2008; Lanis et al., 2010), production of binary toxin (McDonald et al., 2005), higher rates of sporulation (Merrigan et al., 2003; Akerlund et al., 2008), and increased antibiotic resistance (McDonald et al., 2005). 


\section{VIRULENCE FACTORS OF C. DIFFICILE}

Several factors have been implicated in the virulence of $C$. difficile including adhesins (Waligora et al., 2001), extracellular enzymes (Savariau-Lacomme et al., 2003), fimbrae (Borriello et al., 1990), flagella (Delmee et al., 1990; Stabler et al., 2006), capsule (Borriello et al., 1990), and a paracrystalline S-layer (Karjalainen et al., 2001; Sebaihia et al., 2006). In addition, C. difficile produces three secreted protein toxins: TcdA, TcdB, and the binary toxin CDTab. CDTab is an actin-specific ADPribosyltransferase that is homologous to iota toxin from C. perfringens (Popoff et al., 1988; Perelle et al., 1997). Many pathogenic strains do not produce CDTab (Rupnik et al., 2003), and the role of binary toxin in pathogenesis is unclear (Perelle et al., 1997; Barbut et al., 2005; Geric et al., 2006).

$\mathrm{TcdA}$ and $\mathrm{TcdB}$ are 308 and $270 \mathrm{kDa}$ proteins, respectively, with $49 \%$ identity and $63 \%$ similarity. They belong to a larger family of large clostridial toxins (LCTs) which includes lethal and hemorrhagic toxins from $C$. sordellii (TcsL and TcsH), $\alpha$-toxin from C. novyi $(\operatorname{Tcn} \alpha)$, and large cytotoxin from $C$. perfringens (TpeL) (Table 1). LCTs are homologous toxins that inactivate host Rho and Ras family guanosine triphosphatases (GTPase) by glucosylation. The Rho and Ras family GTPases are master regulators of a number of vital cellular processes including cycle progression, cell-cell adhesion, cytokinesis, secretion, and maintenance of the cytoskeleton (Bishop and Hall, 2000; Jank et al., 2007b).

\section{ROLES OF TcdA AND TcdB IN VIVO EFFECTS OF THE TOXINS ON CELLS}

The most obvious change in cells treated with TcdA or TcdB is the loss of cytoskeletal structure. Both toxins induce rounding in a wide range of cell types. Although TcdA and TcdB have the same general mechanism of action, they have several phenotypic differences. In the capacity to round cells, TcdB is $100-10,000$ times more potent than TcdA in many cell types (Donta et al., 1982; Tucker et al., 1990; Aktories, 1997; Chaves-Olarte et al., 1997).

TcdA and TcdB also cause cells to die. Cell death and cellrounding are distinct events in intoxication (Qa'Dan et al.,

\section{Table 1 | Large clostridial toxins.}

\begin{tabular}{lllll}
\hline Toxin & Species & Mol. weight & $\begin{array}{l}\text { Lethal } \\
\text { activity }\end{array}$ & Targets \\
\hline TcdA & difficile & $308 \mathrm{kDa}$ & $50 \mathrm{ng}$ & Rho, Rac, Cdc42, Rap \\
TcdB & difficile & $270 \mathrm{kDa}$ & $50 \mathrm{ng}$ & Rho, Rac, Cdc42 \\
TcdB-F & difficile & $270 \mathrm{kDa}$ & $50 \mathrm{ng}$ & Rac, Ras, Ral, Rap \\
TcsH & sordellii & $\sim 300 \mathrm{kDa}{ }^{3}$ & $75 \mathrm{ng}$ & Rho, Rac, Cdc42 \\
TcsL & sordellii & $270 \mathrm{kDa}$ & $5 \mathrm{ng}$ & Rac, Ras, Ral, Rap \\
Tcn $\alpha$ & novyi & $250 \mathrm{kDa}$ & $5-10 \mathrm{ng}$ & Rho, Rac, Cdc42 \\
TpeL & perfringens & $191 \mathrm{kDa}$ & $16 \mu \mathrm{g}$ & Rac, Ras, Ral, Rap \\
\hline
\end{tabular}

${ }^{1}$ Amounts listed are for one mouse lethal dose and were obtained by intraperitoneal injection (Ball et al., 1993; Amimoto et al., 2007).

2 TcdB-F is a variant $T c d B$ produced by the $T c d A^{-} T_{c d B}+$ strain 1470 (ChavesOlarte et al., 1999).

3 The amino acid sequence for TCSH is unknown. The estimated molecular weight is based on SDS-PAGE (Martinez and Wilkins, 1988).
2002). To distinguish between the two events, cell-rounding and cell death are sometimes referred to as the cytopathic effect and cytotoxic effect, respectively. TcdA and TcdB have been reported to cause death through a number of different mechanisms including p53-dependent and p53-independent apoptosis, caspase-dependent and caspase-independent apoptosis, as well as necrosis (Warny and Kelly, 1999; Hippenstiel et al., 2002; Qa’Dan et al., 2002; Kim et al., 2005; Matarrese et al., 2007; Nottrott et al., 2007).

TcdA and TcdB have a number of effects on cells that do not necessarily result in rounding or death, yet may contribute to pathogenesis. Inactivation of Rho GTPases by TcdA and TcdB results in the disruption of cell-cell junctions, which may contribute to the increased epithelial permeability and lumenal fluid accumulation associated with CDAD (Feltis et al., 2000; Johal et al., 2004). Both toxins also induce the secretion of cytokines in epithelial and immune cells. These include tumor necrosis factor, IL-1, IL-6, and IL-8 (Savidge et al., 2003). IL-8, in particular, is thought to play a pivotal role in $C$. difficile pathogenesis. IL8 is involved in the recruitment and activation of neutrophils, which are present in high amounts at sites of $C$. difficile associated inflammation. A polymorphism in the IL-8 gene has been associated with susceptibility to recurrent CDAD (Jiang et al., 2006).

\section{EFFECTS OF THE TOXINS IN ANIMALS}

The activities of purified TcdA and TcdB have been investigated in a number of animal models including mice, rats, rabbits, and hamsters. Although the manifestations of disease vary in the different animals, in these models TcdA induces fluid accumulation and inflammation within the intestinal tract, whereas TcdB causes minimal or no intestinal pathology (Lyerly et al., 1982, 1985; Mitchell et al., 1986). In the rabbit ligated ileal loops, for example, TcdA induces fluid accumulation with comparable activity to cholera toxin (Lyerly et al., 1982). Unlike cholera toxin, the toxin also causes extensive tissue damage and the accumulated fluid is hemorrhagic (Lyerly et al., 1982, 1988). TcdB has no effect in this assay. Likewise, when TcdA and TcdB are given to mice and hamsters intragastrically, TcdA causes intestinal hemorrhage, diarrhea, and death, but TcdB has no effect (Lyerly et al., 1985). TcdB, is however, a potent toxin toward these animals when administered by other routes. When given by intraperitoneal injection, $\mathrm{TcdA}$ and $\mathrm{TcdB}$ are both lethal toxins with similar potencies (Table 1) (Ball et al., 1993).

Based on these early studies, TcdA was referred to as the enterotoxin, and TcdB, because of its $\sim 1000$-fold higher cytopathic potency toward cultured cells, was referred to as the cytotoxin. It was proposed that TcdA induced the initial damage in the colon where TcdB alone was relatively inert. After TcdA had disrupted the intestinal epithelium, TcdB might then access and act on other tissues (Lyerly et al., 1988). This model implicated TcdA as the key virulence factor in disease and TcdB as, perhaps, an accessory virulence factor. In support of this model, Lyerly et al. showed that if TcdB is given to hamsters with damaged intestines or together with sublethal doses of TcdA the animals die. Furthermore, a humoral immune response against TcdA correlates with protection from disease both in humans and in 
animal models (Warny et al., 1994; Kyne et al., 2001; Giannasca and Warny, 2004; Babcock et al., 2006).

More recently, a number of pieces of evidence have shown $\mathrm{TcdB}$ has a much more important role in disease than previously appreciated. Since the 1990s, a number of pathogenic strains have been identified that produce TcdB, but not TcdA. These $\mathrm{TcdA}^{-} \mathrm{TcdB}^{+}$strains cause the same range of symptoms as $\mathrm{TcdA}^{+} \mathrm{TcdB}^{+}$strains in humans, and are pathogenic in animal models (Sambol et al., 2000). Thus TcdA is not essential for pathogenesis. To date, no pathogenic $\operatorname{TcdA}^{+} \mathrm{TcdB}^{-}$clinical isolates have been identified. In addition, there have been reports that while TcdB may not be enterotoxic in animal models, it is toxic toward human colonic tissues. Riegler et al. tested the effects of TcdA and TcdB on human colonic explants and found that TcdB was $\sim 10$ times more potent than TcdA at disrupting the integrity of the membrane (Riegler et al., 1995). Savidge et al. have demonstrated the toxicity of TcdB in a chimeric mouse model of disease where a human fetal intestinal xenograft is transplanted into an immunodeficient mouse (Savidge et al., 2003). When challenged with either TcdA or TcdB, the human xenografts exhibited intestinal epithelial cell damage with marked necrosis, increased mucosal permeability, and acute mucosal inflammation.

Elucidating the roles of TcdA and TcdB in pathogenesis has been slow, partially due to the lack of genetic tools for the manipulation of C. difficile (O'Connor et al., 2006). In 2009, Lyras et al. reported results from animal infections conducted with $t c d A$ and $t c d B$ mutants (Lyras et al., 2009). Clindamycin-treated hamsters were challenged with isogenic strains lacking either toxin. Surprisingly, knocking out TcdA seemed to have no effect on the virulence of the strain. Strains lacking TcdB, however, were avirulent. Death of the hamster was the only reported phenotype, so it is not clear if the $\mathrm{TcdA}^{+} \mathrm{TcdB}^{-}$strains had subtler pathological effects. In similar experiments carried out by Kuehne et al., TcdA and TcdB deficient mutants were both shown to have pathologic effects in hamsters (Kuehne et al., 2010). Efforts to further evaluate the roles of toxin in the context of mouse infection models are on-going (Chen et al., 2008).

Although TcdA and TcdB have long been accepted as the primary virulence factors of $C$. difficile, it is clear that the two toxins have distinctive properties both in animals and on cells. In addition, several isoforms of TcdB have been noted. TcdB from the NAP1/027 strain R20291 is >1000-fold more cytopathic than TcdB from the prototypical 630 strain on a number of cell lines (Stabler et al., 2009). $\mathrm{TcdA}^{-} \mathrm{TcdB}^{+}$strains (e.g., 1470 and 8864) produce variant forms of $\mathrm{TcdB}$ that have altered substrate specificity. Understanding the molecular roles of $\mathrm{TcdA}, \mathrm{TcdB}$, and variant toxins in pathogenesis is important for the development of therapeutic strategies aimed at disrupting the action of these toxins.

\section{TcdA AND TcdB STRUCTURE AND MECHANISM OF ACTION}

TcdA and TcdB are homologous AB toxins. They can be divided into two components: an enzymatic A subunit and a B subunit involved in the delivery of the A subunit into the target cell (Figure 1). The A subunit is an N-terminal glucosyltransferase domain (GTD) that inactivates host GTPases by glucosylation.
Three additional domains within the $\mathrm{B}$ component are responsible for delivery of the GTD to the cytosol of the host cell. These include a receptor-binding domain, a "delivery" or pore-forming domain, and an autoprotease domain. The mechanism of action can be divided into four steps that are mediated by the four known domains: (1) binding/internalization, (2) pore-formation and translocation of the GTD across the membrane, (3) release of the GTD by autoproteolysis, and (4) inactivation of host GTPases by glucosylation (Figure 1B). The four main steps of intoxication are discussed below.

\section{RECEPTOR-BINDING}

The C-termini of TcdA and $\mathrm{TcdB}$ consist of highly repetitive structures termed combined repetitive oligopeptides (CROPs) which are contained within amino acids 1832-2710 and 18342366, respectively (von Eichel-Streiber and Sauerborn, 1990; Ho et al., 2005). The CROPs are made up of multiple 19-24 amino acid short repeats (SRs) and 31 amino acid long repeats (LRs) (von Eichel-Streiber and Sauerborn, 1990; Jank et al., 2007b). The TcdA CROPs domain comprises 32 SRs and 7 interspersed LRs (Figure 2A). The domain in TcdB is considerably shorter and contains 19 SRs and 4 LRs. Together the LR and SRs form cell wall binding motifs that bind sugar moieties on the surface of host cells (von Eichel-Streiber et al., 1992a,b). Cell wall binding motifs from TcdA were initially shown to bind $\alpha$-Gal- $(1,3)-\beta$-Gal- $(1,4)-$ $\beta$-GlcNAc (Krivan et al., 1986). However, this sugar is not present on human cells (Tucker and Wilkins, 1991). TcdA has since been reported to bind to the human $\mathrm{I}, \mathrm{X}$, and $\mathrm{Y}$ blood antigens as well as a human glycosphingolipid which all have a core $\beta$-Gal-(1,4)$\beta$-GlcNAc structure (Tucker and Wilkins, 1991; Teneberg et al., 1996). It is not known which of these, if any, serve as the native ligand in the human colon.

Two proteins have been implicated as receptors for TcdA. Rabbit sucrose-isomaltase was first shown to serve as a receptor for TcdA in the rabbit ileum (Pothoulakis et al., 1996). Binding to sucrose-isomaltase was inhibited by galactosidase treatment, indicating that the toxin binds glycosyl modification(s) on the protein, but the identity of the sugar(s) is unknown (Pothoulakis et al., 1996). Rabbit sucrose-isomaltase cannot be the only receptor for TcdA, because many cells and tissues, including the human colonic epithelium, do not express this protein yet are sensitive to TcdA (Pothoulakis et al., 1996). More recently, human gp96 has been reported as a receptor for TcdA ( $\mathrm{Na}$ et al., 2008). Like sucrose-isomaltase, gp96 is predicted to be glycosylated, but the identities of the saccharides have not been determined. It has not been shown for gp96 whether or not the saccharide modifications are involved in binding TcdA. No receptors have been described for TcdB.

In 2005, Ho et al. published the crystal structure of a fragment of TcdA comprising amino acids 2573-2709 (TcdA CROPs f1) [pdb 2F6E (Ho et al., 2005)]. This fragment contains 4 SRs and 1 LR. The structure revealed that each repeating element consists of a $\beta$-hairpin followed by a loop. In the SRs, the loops are $7-$ 10 amino acids in length, whereas the LR loop contains 18 amino acids. The SRs are packed together in a regular fashion where each repeat is rotated by $\sim 120^{\circ}$ in relation to the previous one (Ho et al., 2005). The repetitive stacking of SRs forms straight, rod-like 


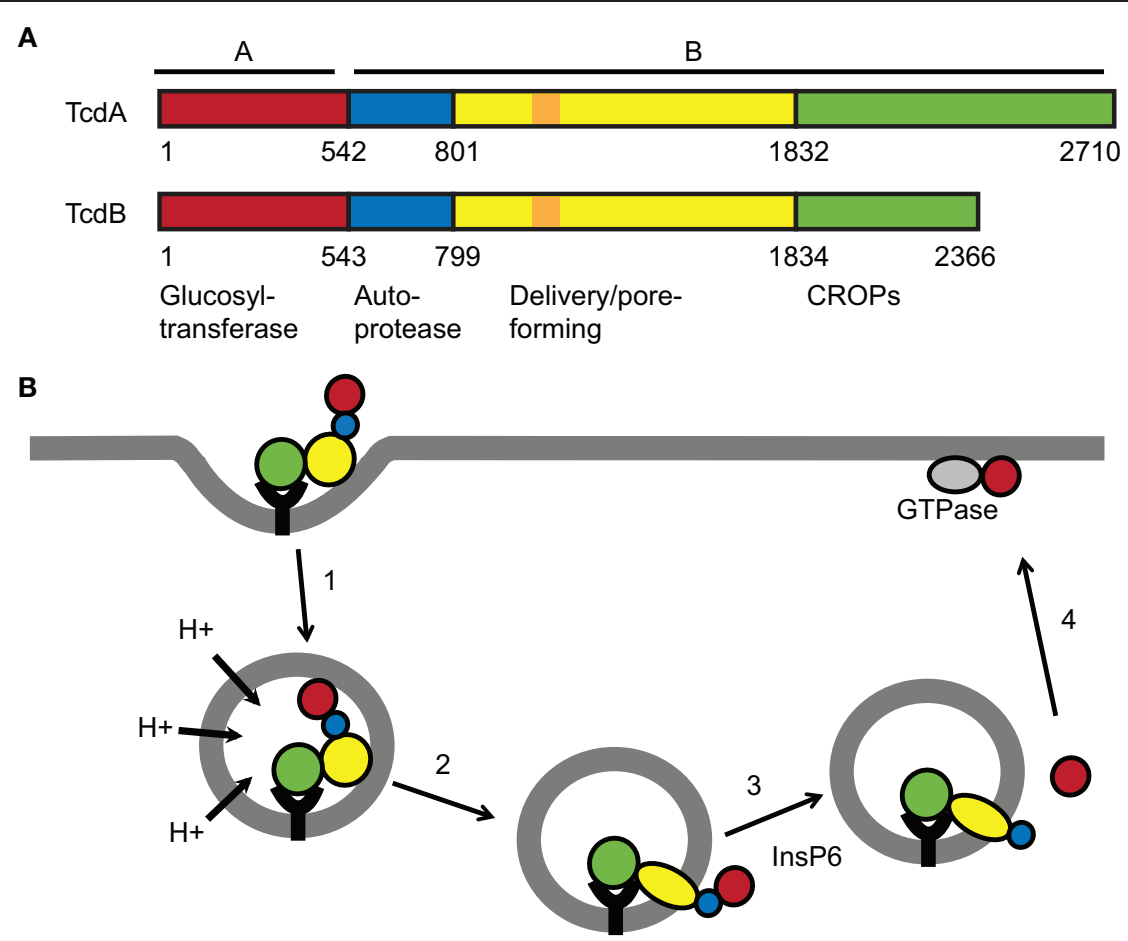

FIGURE 1 | TcdA and TcdB primary structure and mechanism of cellular intoxication. (A) TcdA and $T c d B$ are homologous $A B$ toxins consisting of four domains. The enzymatic $\mathrm{A}$ component is an $\mathrm{N}$-terminal glucosyltransferase domain (GTD) (red). The B component, involved in delivery of the GTD into the cell, has three identified domains: combined repetitive oligopeptides (CROPs) (green), "delivery" or pore-forming (yellow), and autoprotease domains (blue). The orange box represents the hydrophobic region of the delivery domain that has been proposed to form part of the transmembrane pore (amino acids 956-1128 of TcdB). (B) The delivery process is divided into four main steps that are mediated by each of the four domains. (1) The toxin binds to the surface of the cell and is internalized by receptor-mediated endocytosis. (2) Acidification of the endosome triggers the formation of a pore through which the GTD is translocated. (3) The GTD is released into the cytosol by InsP6 dependent autoproteolysis. (4) The GTD glucosylates Rho family GTPases at the cell membrane. structures. The LR's packing with its adjacent SRs disrupts the regular repeating arrangement of the SRs, causing a $\sim 30^{\circ} \mathrm{kink}$ in the rod-like structure (Ho et al., 2005). Using the structure of the TcdA CROPs f1 as a template of SR-SR and SR-LR interactions, Ho et al. constructed a model of the entire TcdA and TcdB CROPs domains (Figure 2B).

The same group later published a co-crystal structure of a larger fragment (f2) of the TcdA C-terminal repeats in complex with an $\alpha$-Gal- $(1,3)-\beta$-Gal- $(1,4)-\beta$-GlcNAc derivative [pdb 2G7C (Greco et al., 2006)]. This structure revealed that the saccharides bind at the junctions formed between LRs and SRs (Figure 2C). Thus, each of the kinked regions in Figure 2B represents a putative saccharide binding side. TcdA has 7 such binding sites, whereas TcdB has 4 . The model taken from these structures implies multivalent binding along an extended binding domain (Greco et al., 2006).

The binding of $\alpha$-Gal- $(1,3)-\beta-G a l-(1,4)-\beta$-GlcNAc is shown in Figures 2C,E. The terminal $\alpha-\mathrm{Gal}$ abuts the large loop of the LR and makes several hydrogen-bonding contacts with residues of the loop (e.g., Gln2638) (Figure 2D). The central $\beta$-Gal moiety sits with its methoxy group pointed down into a small acidic cleft formed in part by Glu2623. The oxygen of the methoxy group hydrogen bonds with Lys 2661 of the SR. The GlcNAc group interacts with a number of SR residues including a hydrogen bond formed with Ser2660. The residues pointed out here (Glu2623, Gln2638, and Ser2660, Lys2661) are all strictly conserved in the saccharide binding repeats of the TcdA CROPs. Yet, these residues are strikingly different in the TcdB CROPs. Glu2623, for example, which contributes to the small acidic pocket where the $\beta$-Gal binds is replaced by a bulky, basic residue (lysine) in each of the TcdB LRs. Thus, while the TcdB CROPs are predicted to have a similar fold to the TcdA CROPs, the residues comprising the TcdA-saccharide binding sites are radically different. This provides a likely explanation for why $\mathrm{TcdB}$ does not bind the $\beta$-Gal- $(1,4)-\beta$-GlcNAc with the affinity of TcdA.

In addition to differences between $\mathrm{Tcd} A$ and $\mathrm{TcdB}$, it is also of note that the C-terminal repeats of $\mathrm{TcdB}$ from the prototypical 630 strain and TcdB from the hypervirulent R20291 strain differ considerably. The CROPs from the two toxins are $88 \%$ identical, with some of the individual repeats having less than $80 \%$ identity (Lanis et al., 2010). Interestingly, the TcdB variant from the $\mathrm{TcdA}^{-} \mathrm{TcdB}^{+}$strain 8864 has CROPs similar to the R20291 TcdB (97\% identical); whereas, the variant from the $\mathrm{TcdA}^{-} \mathrm{TcdB}^{+}$strain 1470 resembles the prototypical strain (99\% identical). Most of the differences in sequence are in the SRs, and the putative saccharide binding sites are largely conserved. It will 
A

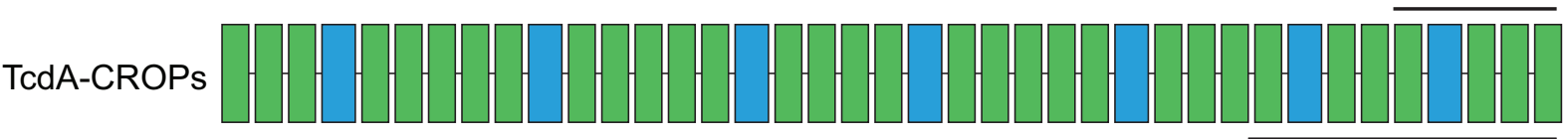

f2 - Greco, et al.

TcdB-CROPs

B

TcdA-CROPs

TcdB-CROPs
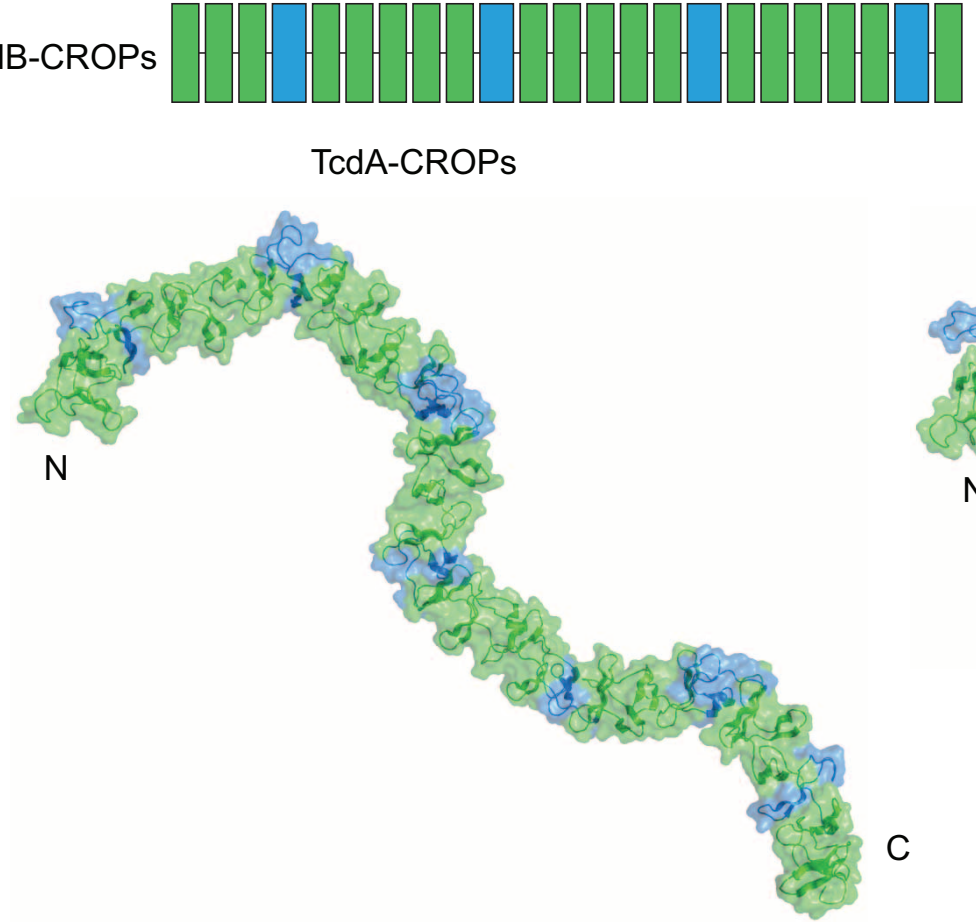

C

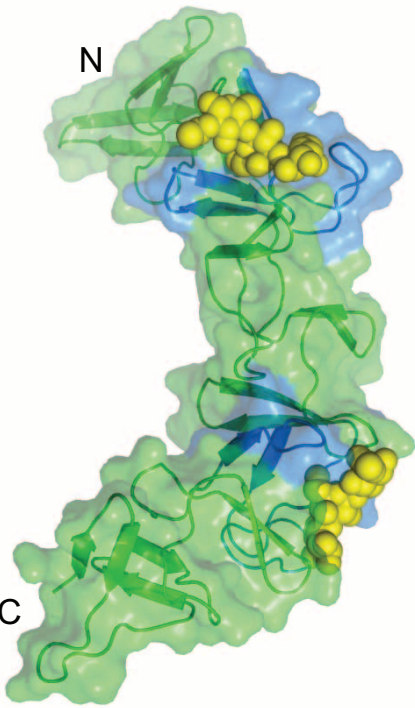

D

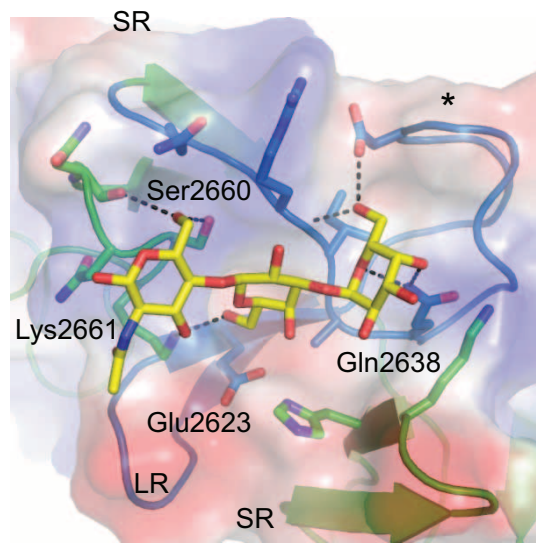

E

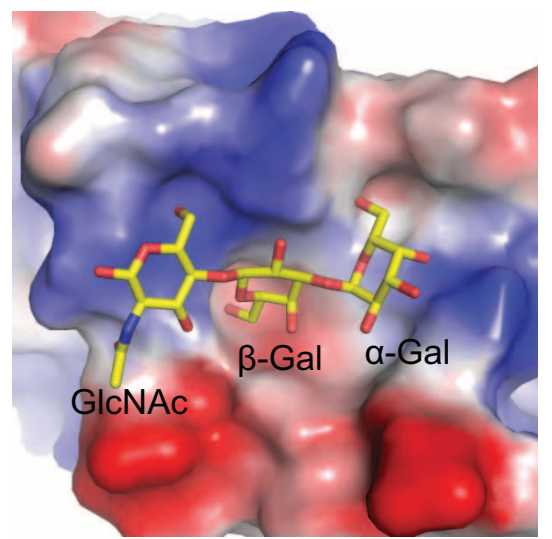

FIGURE 2 | Structure of the CROPs domain. (A) The TcdA CROPs domain is made up of 32 short repeats (SRs) with seven interspersed long repeats (LRs), which are represented by green and blue boxes, respectively. The TcdB CROPs domain consists of 19 SRs and 4 LRs. (B) Models of the TcdA and TcdB C-terminal repeats were constructed based on the structure of TcdA CROPs f1 (Ho et al., 2005). The models are colored as in (A).

(C) Carbohydrate recognition by the TcdA CROPs. The crystal structure of TcdA CROPs f2 (amino acids 2456-2710) is shown with the SRs colored green and LRs colored blue. The head-group of the bound liposaccharide $\alpha$-Gal- $(1,3)-\beta$-Gal- $(1,4)-\beta$-GlcNAcO $\left(\mathrm{CH}_{2}\right)_{8} \mathrm{CO}_{2} \mathrm{CH}_{3}$ is shown in yellow. (D,E) A close-up view of the trisaccharide-binding pocket formed by an LR and adjacent SR. The electrostatic surface potential is shown with negatively charged surfaces in red and positively charged surfaces in blue [transparent in (D) and opaque in (E)].

In (D) residues that make up the trisaccharide binding pocket are shown as sticks, and hydrogen bonds are shown as dashed lines. The labeled residues are strictly conserved in the saccharide-binding repeats of TcdA but are divergent in $T c d B$. 
be of interest to investigate if and how these amino acid changes impact cell binding.

There are a number of pieces of evidence that suggest that the CROPs are not the only parts of the proteins involved in binding to cells. The homologous toxin TpeL from C. perfringens lacks the C-terminal repeats yet is still toxic, albeit much less potent than its homologs (Table 1) (Amimoto et al., 2007). Moreover, it has been shown that removing the CROPS from TcdA or TcdB attenuates but does not eliminate cytopathicity suggesting the existence of an additional binding activity outside carbohydrate-binding repeats (Barroso et al., 1994; Genisyuerek et al., 2011; Olling et al., 2011). This has been most thoroughly demonstrated for TcdA. TcdA lacking amino acids 1875-2710, which contains two SRs and no LRs (therefore, no saccharide binding sites), is able to intoxicate HT29 and 3T3 with 5-10-fold less potency than full-length toxin (Olling et al., 2011).

The additional binding activity may be encoded in the region preceding the C-terminal repeats. While removal of the CROPs of TcdB only partially reduces cytopathic potency, truncation to 1-1500 or 1-1529 completely attenuates cytopathicity (Barroso et al., 1994; Genisyuerek et al., 2011). If the receptor-binding domain from diphtheria toxin is attached to the truncated TcdB 1-1500, it regains its ability to intoxicate cells (Genisyuerek et al., 2011).

\section{PORE FORMATION}

TcdA and TcdB enter the cell by clathrin-mediated endocytosis (Papatheodorou et al., 2010). Once the toxins have been internalized, the glucosyltransferase must be delivered across the endosomal membrane. Endosomal acidification is thought to induce structural changes in the delivery domain that expose hydrophobic segments. These hydrophobic regions insert into the host membrane forming a pore through which the glucosyltransferase domain can pass. This model, which was initially based on analogy to other pore-forming $\mathrm{AB}$ toxins, is now supported by several studies.

Qa'Dan et al. have shown that acidification causes structural rearrangements in $\mathrm{TcdB}$. The authors demonstrated that upon reduction of $\mathrm{pH}$ to 4.0 , TcdB exhibits differences in native tryptophan fluorescence, protease susceptibility, and results in the exposure of hydrophobic surfaces (Qa'Dan et al., 2000). Barth et al. demonstrated that acidification, not only induces conformational changes, but also triggers pore formation. Chinese hamster ovary (CHO) cells were preloaded with ${ }^{86} \mathrm{Rb}^{+}$, and then treated with TcdB. Under acidic conditions, ${ }^{86} \mathrm{Rb}^{+}$was released into supernatant when $\mathrm{TcdB}$ was present, indicating that TcdB inserts into the plasma membrane and forms ion channels. The authors showed that $\mathrm{TcdB}$ can induce ion channels in artificial lipid bilayers at low pH (Barth et al., 2001). Barth et al. and Qa'Dan et al. demonstrated that these results are also applicable in the natural intoxication of cells. Treatment of cells with pharmacological inhibitors of endosomal acidification (e.g., bafilomycin A1) retards the toxic effects of $\mathrm{TcdB}$, presumably by inhibiting pore formation (Qa'Dan et al., 2000; Barth et al., 2001).

Most studies on the pore-forming activity of the $C$. difficile toxins have used TcdB from strain 630. TcdA has also been shown to form channels in cells and in artificial bilayers (Giesemann et al.,
2006). However, TcdA requires cholesterol for pore-formation whereas TcdB does not. TcdB from the NAP1/027 strain R20291 has been shown to enter cells more quickly and undergo $\mathrm{pH}$ dependent conformational change at a higher $\mathrm{pH}$ than TcdB from strain 630 (Lanis et al., 2010). The molecular bases for these differences are unknown.

Pore formation and translocation are thought to be mediated by the central delivery domain ( aa 801-1831). BLAST analysis of the delivery domain reveals two distinct regions of homology (Pruitt et al., 2010). We have termed these two regions D1 $(\sim 801-1400)$ and D2 ( 1401-1831). Within D1, amino acids 956-1128 are particularly hydrophobic and have been hypothesized to compose at least part of the transmembrane pore (von Eichel-Streiber and Sauerborn, 1990; von Eichel-Streiber et al., 1992a). Genisyuerek et al. have recently constructed a series of TcdB truncations to delineate the region of the toxin responsible for pore-formation (Genisyuerek et al., 2011). Proteins containing residues 1-990 and 830-2366 (or 830-1025) are capable of forming membrane channels at low $\mathrm{pH}$ suggesting that the amino acids 830-990 contain the minimal pore-forming region (Genisyuerek et al., 2011).

Within this region, the authors identified two residues (Glu970 and Glu976) that are involved in pore-formation (Genisyuerek et al., 2011). When both residues are mutated to lysine, the toxin is reduced in its ability to form pores at low $\mathrm{pH}$ and in its cytopathic potency. These residues may be involved in the $\mathrm{pH}$ sensing mechanism. At low $\mathrm{pH}$, these acidic residues might be neutralized by protonation, which could facilitate their insertion into the membrane. These residues are not strictly conserved among LCTs, but most of the toxins do have acidic residues at these positions. TcdA, for example, has aspartate residues Asp972 and Asp978 which could play a similar role. The variant TcdB from strain 8864 is an exception; the residue corresponding to Glu970 is a glycine. The pore-forming activity of this toxin has not been studied.

The finding that amino acids 830-990 contains the minimal pore-forming sequence raises the question of what roles the other 875 residues in the delivery domain play in intoxication. The Cterminal part of the delivery domain (D2) may have a role in binding to cells as suggested in the previous section. So far, very little is known about the structure of the delivery domains of $\mathrm{TcdA}$ or TcdB in either the soluble or membrane states. It is also not known whether the toxins must oligomerize in order to form a pore. Understanding the structural changes that allow TcdA or TcdB to go from being soluble proteins to membrane pores is an exciting structural problem important for understanding the function of these proteins.

\section{AUTOPROTEOLYSIS}

LCTs are made and secreted as single polypeptide chains. It was unknown for many years whether the toxin remained intact or if the A component (GTD) was released into the cell as is typical for other AB toxins. It was first shown in 2003 that TcdB is proteolytically processed and that only the N-terminal GTD is released into the cytosol (Pfeifer et al., 2003). The cleavage site was localized between Leu543 and Gly544, and it was revealed that cleavage was mediated by a component of the target cell cytosol (Rupnik et al., 
2005). It was thought that this proteolytic event was mediated by a host protease (Rupnik et al., 2005).

When Reineke et al. tried to identify the host factor required for cleavage of $\mathrm{TcdB}$, they found that the host factor was not a protein but an inositol-phosphate (Reineke et al., 2007). The most active of the inositol-phosphates was inositol hexakisphosphate (InsP6) (Reineke et al., 2007). When mixed with purified LCTs, InsP6 alone was enough to induce cleavage. Egerer et al. confirmed that cleavage was stimulated by InsP6 and showed that a cysteine protease domain (CPD) adjacent to the GTD is responsible for cleavage (Egerer et al., 2007).

The CPD was identified based on its homology to a CPD that had just been discovered in the RTX toxin from Vibrio cholerae (Sheahan et al., 2007). As in the LCTs, the V. cholerae RTX (VcRTx) toxin CPD facilitates the release of enzymatic moieties into the target cell, and it is also activated by InsP6 (Prochazkova and Satchell, 2008). Crystal structures of the VcRTx [pdb 3EEB, 3FZY (Lupardus et al., 2008; Prochazkova et al., 2009)], TcdA [pdb 3 HO6 (Pruitt et al., 2009)], and TcdB [pdb 3PEE (Puri et al., 2010)] CPDs have revealed that these domains share a similar structure and mechanism of InsP6-induced activation. The domains have a central $\beta$-sheet flanked by a number of $\alpha$-helices (Figure 3). The CPDs from TcdA and TcdB are larger than that of VcRTx, containing extended helical regions, an inserted $\beta$-strand, and a C-terminal extension, but the core fold of the structures is conserved (Lupardus et al., 2008; Pruitt et al., 2009). Three conserved catalytic residues, cysteine, histidine, and aspartate, cluster on the edge of the $\beta$-sheet (shown as orange sticks in Figure 3 ). InsP6 is bound at a separate site on one face of the $\beta$-sheet in a basic, lysine-rich pocket (Figure 3). The InsP6 binding pocket is separated from the catalytic triad by a structure termed the $\beta$-flap (Figure 3, $\beta$-flap colored purple).

The aspartate, histidine, and cysteine residues of the catalytic site have been shown to be essential in the auto-proteolytic processing of VcRTx (Sheahan et al., 2007), TcdA (Pruitt et al.,
2009), and TcdB (Sheahan et al., 2007). However, they do not form a conventional catalytic triad arrangement wherein the histidine forms a hydrogen bond with the cysteine making the cysteine more nucleophilic. The cysteine and histidine residues are, instead, separated by a large cleft. Rather than acting to increase the nucleophilicity of the cysteine, His655 may be important for stabilizing the oxyanion intermediate or protonating the leaving group (Prochazkova et al., 2009; Pruitt et al., 2009).

The discovery of the CPD in TcdA and TcdB presents a potential new target for therapeutics inhibiting the toxins. Puri et al. have developed a number of small molecule inhibitors of TcdB that act by covalent modification of the catalytic cysteine (Puri et al., 2010). A crystal structure of the TcdB CPD was determined bound to one of these compounds, acyl-GlySer-Leu-acyloxymethyl ketone (Ac-GSL-AOMK) (Figure 4) [pdb 3PA8 (Puri et al., 2010)]. Ac-GSL-AOMK is a mimic of the native TcdB substrate (Gly-Ser-Leu $\downarrow$ Ser-Glu-Asp). The leucine side chain of the inhibitor binds in a hydrophobic pocket immediately adjacent to the catalytic site (Figure 4). The hydrophobic residues involved in binding to the substrate are largely conserved among LCTs and RTX CPDs, and all of these CPDs cleave after a leucine. The crystal structure of an inactive VcRTX CPD with the substrate bound reveals that this protease has a similar mechanism of substrate binding [pdb 3FZY (Prochazkova et al., 2009)].

The CPD structures were obtained in the presence of InsP6. NMR, circular dichroism, and limited proteolysis of the TcdA $\mathrm{CPD}$ suggests that the domain is folded in both apo- and InsP6-bound proteins but that InsP6 binding confers stability and induces significant structural change (Pruitt et al., 2009). Recent work by Shen et al. has demonstrated that the TcdB $\mathrm{CPD}$ exists in a dynamic equilibrium between active and inactive states (Shen et al., 2011). InsP6 binding shifts the equilibrium markedly toward the active conformation. Shen et al. show by mutational analysis that the $\beta$-flap plays an important role in the

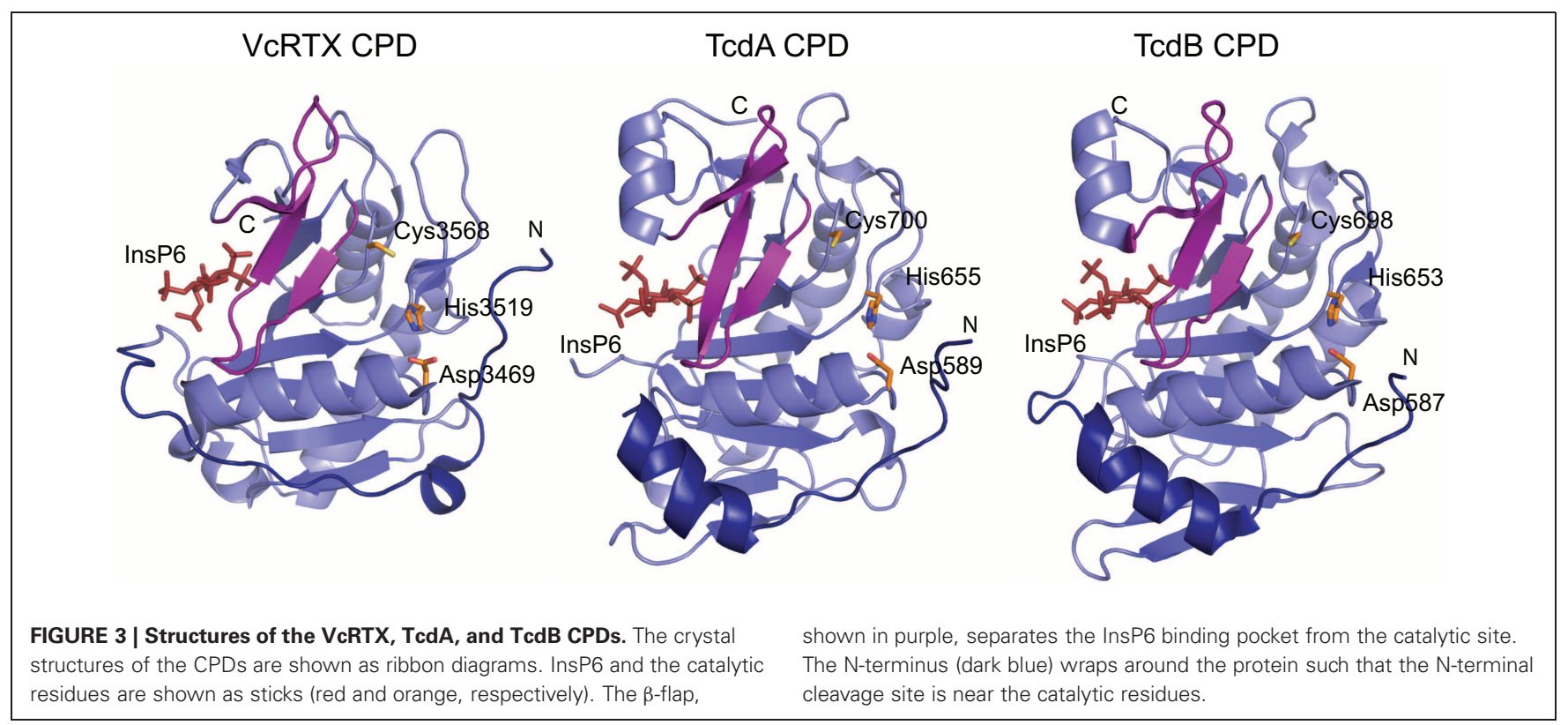




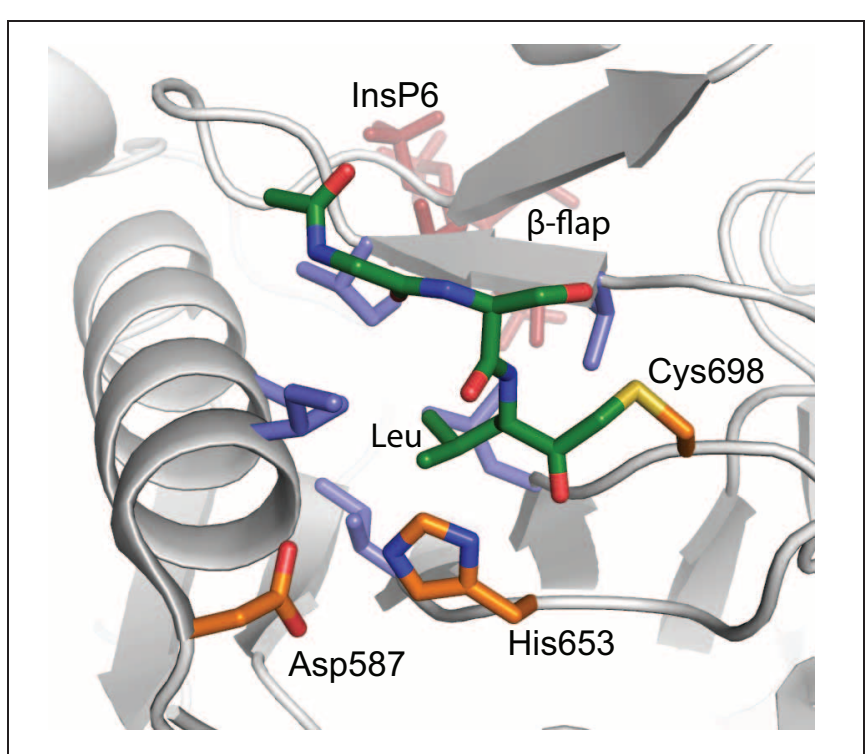

FIGURE 4 | Inhibition of the TcdB by covalent modification of the active site. The TcdB CPD catalytic site is shown with the substrate mimic acyl-Gly-Ser-Leu-acyloxymethyl ketone (Ac-GSL-AOMK) (green) bound. Catalytic residues are shown in orange and InsP6 is shown in red. The leucine side chain of the Ac-GSL-AOMK is bound in a hydrophobic substrate binding pocket (blue).

allosteric activation mechanism by coupling the InsP6-binding and catalytic sites.

Cleavage is not equivalent between TcdA and TcdB. TcdB holotoxin is more sensitive than TcdA holotoxin to InsP6induced cleavage in in vitro reactions (Kreimeyer et al., 2011). The basis for this difference is not readily apparent from the structures of the CPD domains from the two toxins. It is possible that these differences in sensitivity to InsP6 are due to areas outside the domain. In our observations, the TcdA holotoxin undergoes processing much less efficiently than a small fragment containing the protease domain (510-809). Therefore, factors outside the protease domain affect cleavage, possibly to prevent premature processing.

Collectively, the aforementioned structural and biochemical data have revealed that InsP6-mediated autoproteolysis is a conserved mechanism used by diverse toxins to release their cargo into eukaryotic cells. This novel autoprocessing mechanism is reviewed in greater detail in (Shen, 2010a,b) and (Egerer and Satchell, 2010).

\section{GLUCOSYLTRANSFER}

The N-termini of the LCTs contain a $63 \mathrm{kDa}$ GTD which is released into the cell and inactivates small GTPases. GTPases are molecular switches that cycle between active GTP-bound and inactive GDP-bound states. Upon binding GTP, GTPases undergo a conformational change allowing them to interact with several effector molecules (Bishop and Hall, 2000; Aktories and Barbieri, 2005). The repertoire of effector molecules is extensive and includes protein and lipid kinases, phosphatases, lipases, and scaffolding proteins. The downstream signaling cascades induced by activation of Rho family GTPases are principally involved in the regulation of the cytoskeleton and processes requiring cytoskeletal rearrangements.

TcdA and TcdB preferentially act on GDP-bound, membrane associated Rho GTPases (Just et al., 1995; Genth et al., 1999). Using UDP-glucose as a co-substrate, the toxins inactivate Rho proteins by monoglucosylation of Thr37 (Thr35 of Rac and Cdc42) (Aktories and Just, 1995; Just et al., 1995). Thr37 is located in the switch I region which is important for binding effectors and regulatory proteins (Genth et al., 1999; Aktories and Barbieri, 2005; Jank et al., 2007b). Glucosylated Rho GTPases are no longer able to interact with regulatory molecules or many of its effectors, and therefore, numerous downstream signaling pathways are interrupted (Herrmann et al., 1998; Sehr et al., 1998; Genth et al., 1999; Aktories and Barbieri, 2005; Jank et al., 2007b).

Based on in vitro experiments, TcdA and $\mathrm{TcdB}$ can target RhoA, RhoB, RhoC, RhoG, Rac1, Cdc42, and TC10 (Jank et al., 2007b; Genth et al., 2008). TcdA has been reported to modify the additional substrates Rap1A and Rap2A which are more closely related to Ras family proteins (Chaves-Olarte et al., 1997). TcsH and Tcn $\alpha$ also target Rho family substrates (Table 1) (Genth et al., 1996; Selzer et al., 1996). TcsL and TpeL, on the other hand, act mostly on Ras family proteins such as H-Ras, Ral, and Rap (Nagahama et al., 2011). They can target Rac but not Rho. Like the Rho proteins, the Ras GTPases are involved in a large number of cellular signaling pathways. They have important roles in the regulation of cell-cell junctions, cell proliferation, and survival (Raaijmakers and Bos, 2009).

The TcdB variants produced by strains 1470, 8864, and C34 modify Ras family substrates (Chaves-Olarte et al., 1999; Mehlig et al., 2001; Huelsenbeck et al., 2007). These toxins are sometimes referred to as functional hybrids because most of the TcdB protein is the same as in prototypical strains, but the GTD modifies the same substrates as TcsL. Interestingly, all of the $\mathrm{TcdA}^{-} \mathrm{TcdB}^{+}$strains that have been characterized so far carry these variant toxins. It is not known why some toxins preferentially target Rho family proteins while others target Ras family proteins, but it is clear that the inactivation of these different proteins has different effects on cells (Giry et al., 1995; ChavesOlarte et al., 1999; Mehlig et al., 2001; Huelsenbeck et al., 2007). TcsL and variant TcdBs which modify Ras family proteins cause cells to have a spindle-like appearance (S-type cytopathic effect), whereas treatment with TcdA and prototypical TcdB results in an arborized appearance (D-type cytopathic effect) (Torres, 1991; von Eichel-Streiber et al., 1995; Mehlig et al., 2001).

In 2005, Reinert et al. determined the crystal structure of the TcdB GTD in complex with UDP-glucose [pdb 2BVM (Reinert et al., 2005)]. The structures of the GTDs from three other LCTs, TcdA, TcsL, and Tcn $\alpha$, have also been determined [pdb 3SS1/3SRZ (Pruitt et al., 2012), 2VKD/2VKH, and 2VK9 (Ziegler et al., 2008)]. These structures coupled with biochemical data have shed light on the enzymatic mechanism of glucosyltransfer. The structure of the TcdB GTD is presented in Figure 5. At the core of the structure is a Rossman fold similar to what is seen in other glycosyltransferases belonging to the glycosyltransferase A (GT-A) family (Reinert et al., 2005). In addition to the common GT-A family fold, TcdB has a number of $\alpha$-helical additions (red). These include an $\mathrm{N}$-terminal 90-residue subdomain at 

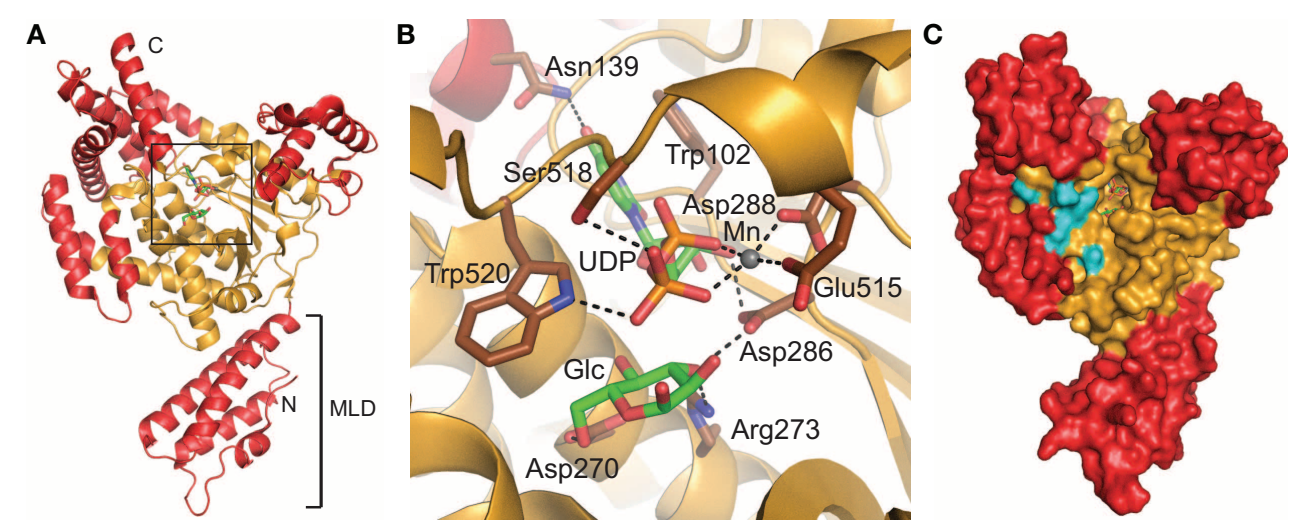

FIGURE 5 | Structure of the TcdB glucosyltransferase domain. (A) The core GT-A fold is shown in orange, and the $\alpha$-helical additions are shown in red. The N-terminal four-helix bundle makes up the MLD. (B) Close up view of the catalytic core. UDP, glucose, and a manganese ion are bound on the surface of the core GT-A fold. The binding pocket is overlayed by a loop comprising residues 517-523. Some of the residues involved in coordinating UDP, Glucose, and $\mathrm{Mn}^{2+}$ are shown as sticks. (C) Surface view of the TcdB GTD as shown in (A). Glu449, Arg455, Asp461, Lys463, and Glu472, residues that have been shown to be involved in GTPase binding, are colored cyan. the "bottom" of the GTD, as presented in Figure 5A, and several other large protuberances at the "top right" and "top left." The Nterminal subdomain has recently been shown to target the GTD to the plasma membrane, the site of the target GTPases (Mesmin et al., 2004; Geissler et al., 2010). This region is, therefore, referred to as the membrane localization domain (MLD). The role of the other $\alpha$-helical additions is unknown, but it has been suggested that these residues are involved in substrate binding (Reinert et al., 2005).

The structure of the TcdB GTD facilitated the identification of important residues in the reaction mechanism. The $\alpha$-anomeric conformation of the glucose is retained in the glucosyltransfer reaction (Vetter et al., 2000), and is thus thought to proceed through a carboxonium intermediate (Ziegler et al., 2008). In the TcdB GTD structure, UDP-glucose is hydrolyzed into UDP and glucose, but both molecules are bound along with the cofactor $\mathrm{Mn}^{2+}$ (Ciesla and Bobak, 1998; Reinert et al., 2005). As in other GT-A proteins, UDP-glucose is bound in a pocket formed by the edge of the $\beta$-sheet and several $\alpha$-helices. A loop consisting of residues 517-523 overlays the binding pocket, and two residues within this loop (Ser518 and Trp520) are involved in binding the phosphate group of UDP (Figure 5B). Figure 5B shows several other key residues that are involved in binding UDP-glucose. The activity of the enzyme is reduced or abolished when any of these residues are mutated (Hofmann et al., 1997; Jank et al., 2007a).

The structure of the TcdB GTD was used as a platform to discover residues that are involved in binding target GTPases. Jank et al. have found 5 residues (Glu449, Arg455, Asp461, Lys463, and Glu472) that when mutated result in loss of substrate modification. These residues are located adjacent to the UDP-glucose binding pocket (cyan in Figure 5C). The transferred glucose is only accessible from this "front" view of the GTD, thus the GTPases must bind to this side of the molecule.

Our lab has recently determined the structure of the TcdA GTD (Pruitt et al., 2012). The overall fold and UDP-glucose binding core of the TcdA and TcdB GTDs are similar, but the surfaces of the two domains are very different (Figure 6). These differences are particularly striking on the proposed GTPase binding surface. Differences on this surface are likely responsible for differential substrate specificities. Notably, the residues which have been shown to be involved in binding of $\mathrm{TcdB}$ to substrates (Figure 5C, cyan) are not conserved among the LCTs. This is also evident when examining TcdB from different strains. TcdB from the prototypical strain 630 and the NAP1/027 R20291 have conserved residues on the substrate binding surfaces. Isoforms from the $\mathrm{TcdA}^{-} \mathrm{TcdB}^{+}$strains 8864 and 1470 , as well as $\mathrm{TcdB}$ from strain C34, have accumulated a large number of mutations on the substrate-binding surface relative to the $\mathrm{TcdB}$ from strain 630 (Figure 7) (Reinert et al., 2005). In 1470, 8864, and C34 $\mathrm{TcdB}$ the toxins have altered substrate recognition, targeting Ras GTPases in addition to Rho family proteins. These GTD variants are typically found in strains lacking TcdA, and may have arisen to compensate for the loss of TcdA, which can modify at least a subset of Ras family proteins (Rap2A).

\section{HOLOTOXIN STRUCTURE}

The structures of the individual domains of TcdA and TcdB have provided considerable insight into the processes of receptorbinding, autoprocessing, and enzymatic inactivation of host GTPases. A structure of the delivery domain would be of considerable interest, as pore-formation and translocation of the GTD are poorly understood steps of the toxin mechanism. However, a complete understanding of toxin function will require an understanding of how these domains interact with each other in the context of the holotoxin. Low resolution maps of the holotoxins have been determined by small angle X-ray scattering (SAXS) and negative stain electron microscopy (EM). The SAXS study was carried out on TcdB and revealed a modular structure into which a structure of the TcdB GTD and models of the CPD and CROPs domain could be placed (Albesa-Jove et al., 2010).

We have used negative stain EM to determine a $25 \AA$ resolution structure of TcdA (Pruitt et al., 2010). The EM structure 


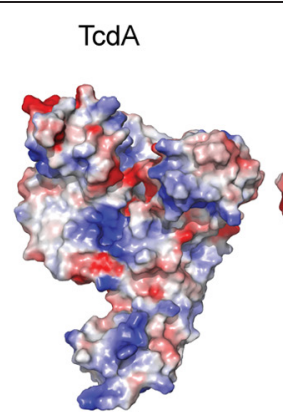

Rho, Rac, Cdc42, Rap

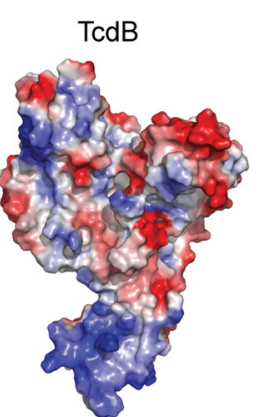

Rho, Rac, Cdc42

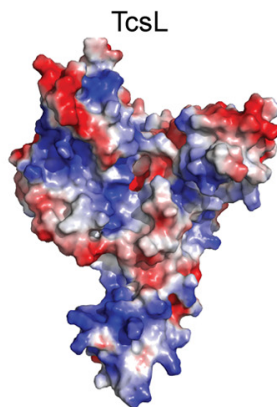

Rac, Ras, Ral, Rap

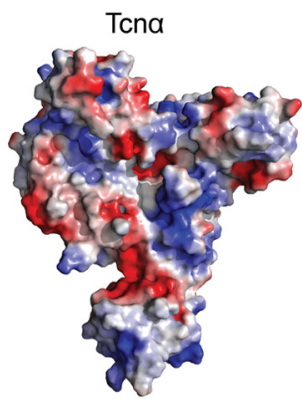

Rho, Rac, Cdc42
FIGURE 6 | The GTPase binding surfaces of the LCTs are diverse. The electrostatic surface potentials of the GTDs of TcdA, $T c d B, T c s L$, and $T c n \alpha$ are shown with basic surfaces in blue and acidic surfaces in red. These varied surfaces likely influence substrate binding specificity. The in vitro substrates are listed below each GTD.

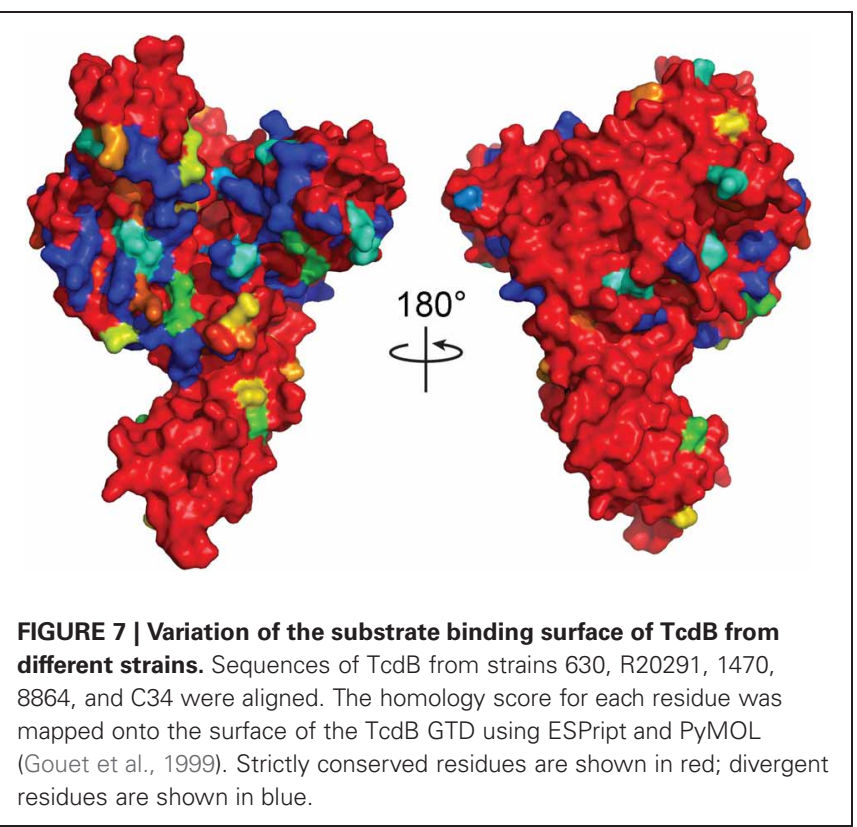

reveals a bi-lobed structure from which there are two protrusions, one long, and curved and the other shorter and wider. Within this map we were able to experimentally localize three of the four domains (Figure 8). The bi-lobed structure comprises the delivery domain. These two lobes may make up the two delivery subdomains, D1 and D2. The shorter of the protrusions represents the GTD, and the long curved protrusion corresponds to the C-terminal repeats, and is consistent with the model of the CROPs domain proposed by Ho et al. (2005).

The structure of TcdA described above represents a single state of the protein. However, these toxins undergo a number of conformational changes in response to environmental signals during cellular intoxication. To begin investigating changes that the toxin must undergo to insert into the membrane and form a pore, we have also determined a structure of TcdA on the EM grid following exposure to low pH (Pruitt et al., 2010). Upon exposure to low $\mathrm{pH}$, there are major changes within the delivery

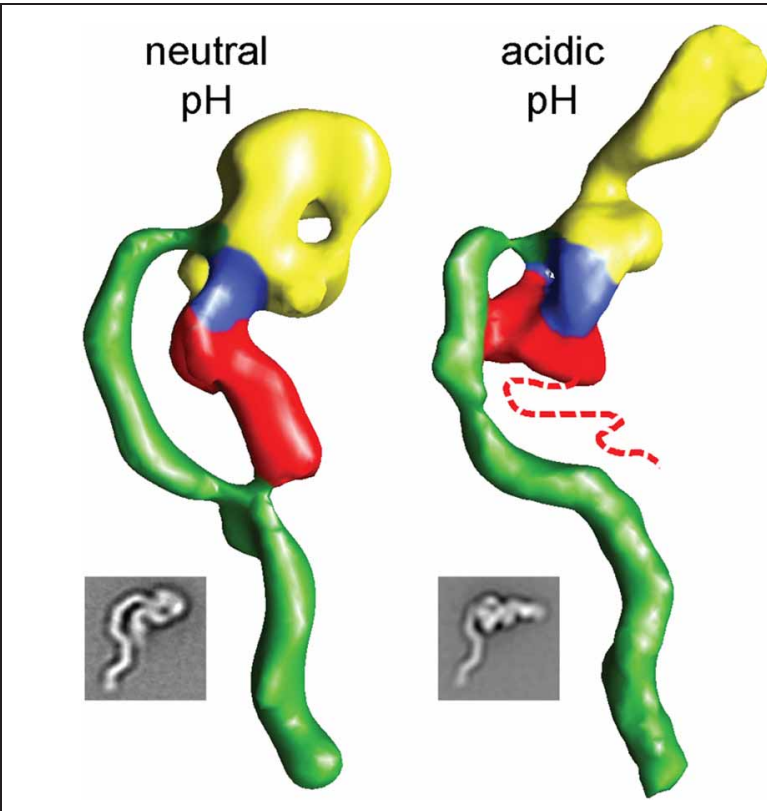

FIGURE 8 | Domain organization of TcdA at neutral and low pH. EM structures are colored by functional domain. GTD, red; CPD, blue; delivery domain, yellow; CROPs, green. The dashed line represents possible unfolding of the TcdA GTD N-terminus at low $\mathrm{pH}$.

and glucosyltransferase domains (Figure 8). The delivery domain takes on a more elongated shape as opposed to the bi-lobed structure. This may reflect a change necessary for exposure of hydrophobic residues that would insert into the membrane. There is also a notable loss of density for the GTD. We suggest that this is due to an unfolding of the GTD at low $\mathrm{pH}$, which would facilitate its translocation through the pore.

These structures have provided and initial map of the organization of the holotoxin. They are limited however, by their low resolution. A combination of structural approaches will likely be necessary to refine this model and understand the structural changes that the toxins must undergo to accomplish the complex task of cargo delivery. 


\section{QUESTIONS FOR FUTURE STUDY}

As the primary virulence factors of $C$. difficile, TcdA and $T c d B$ are prime therapeutic targets for treatment of CDAD. Still, many questions remain regarding how the toxins deliver their cytopathic cargo into target cells. What are the receptors for TcdA and $\mathrm{TcdB}$, and what cells do they target in vivo? Does $\mathrm{D} 2$ have a role in binding to host cells? What is the nature of the pore structure of the toxins? What structural rearrangements are necessary for the toxins to access this pore state? How is the GTD translocated through this pore? How is the autoprotease activity occluded in the holotoxin, and when/how does it become activated?

There is also much to be learned about substrate modification in cells. It is not clear how the GTDs bind their substrates and how the distinct surfaces drive specificity for the target GTPases. Most of what we know about toxin substrate specificity is from in vitro experiments. Membrane localization and host factors likely

\section{REFERENCES}

Akerlund, T., Persson, I., Unemo, M., Noren, T., Svenungsson, B., Wullt, M., and Burman, L. G. (2008). Increased sporulation rate of epidemic Clostridium difficile Type 027/NAP1. J. Clin. Microbiol. 46, 1530-1533.

Aktories, K. (1997). Bacterial toxins that target Rho proteins. J. Clin. Invest. 99, 827-829.

Aktories, K., and Barbieri, J. T. (2005). Bacterial cytotoxins: targeting eukaryotic switches. Nat. Rev. Microbiol. 3, 397-410.

Aktories, K., and Just, I. (1995). Monoglucosylation of lowmolecular-mass GTP-binding Rho proteins by clostridial cytotoxins. Trends Cell Biol. 5, 441-443.

Albesa-Jove, D., Bertrand, T., Carpenter, E. P., Swain, G. V., Lim, J., Zhang, J., Haire, L. F., Vasisht, N., Braun, V., Lange, A., Von Eichel-Streiber, C., Svergun, D. I., Fairweather, N. F., and Brown, K. A. (2010). Four distinct structural domains in Clostridium difficile toxin B visualized using SAXS. J. Mol. Biol. 396, 1260-1270.

Amimoto, K., Noro, T., Oishi, E., and Shimizu, M. (2007). A novel toxin homologous to large clostridial cytotoxins found in culture supernatant of Clostridium perfringens type C. Microbiology 153, 1198-1206.

Babcock, G. J., Broering, T. J., Hernandez, H. J., Mandell, R. B., Donahue, K., Boatright, N., Stack, A. M., Lowy, I., Graziano, R., Molrine, D., Ambrosino, D. M., and Thomas, W. D. Jr. (2006). Human monoclonal antibodies directed against toxins $\mathrm{A}$ and $\mathrm{B}$ prevent Clostridium difficile-induced mortality in hamsters. Infect. Immun. 74, 6339-6347.
Ball, D. W., van Tassell, R. L., Roberts, M. D., Hahn, P. E., Lyerly, D. M., and Wilkins, T. D. (1993). Purification and characterization of alpha-toxin produced by Clostridium novyi type A. Infect. Immun. 61, 2912-2918.

Barbut, F., Decre, D., Lalande, V., Gigandon, A., Espinasse, F., Raskine, L., Robert, J., Mangeol, A., Branger, C., and Petit, J. C. (2005). Clinical features of Clostridium difficile-associated diarrhoea due to binary toxin (actin-specific ADP-ribosyltransferase)-producing strains. J. Med. Microbiol. 54, 181-185.

Barroso, L. A., Moncrief, J. S., Lyerly, D. M., and Wilkins, T. D. (1994). Mutagenesis of the Clostridium difficile toxin B gene and effect on cytotoxic activity. Microb. Pathog. 16, 297-303.

Barth, H., Pfeifer, G., Hofmann, F., Maier, E., Benz, R., and Aktories, K. (2001). Low $\mathrm{pH}$-induced formation of ion channels by Clostridium difficile toxin B in target cells. J. Biol. Chem. 276, 10670-10676.

Bartlett, J. G. (1994). Clostridium difficile: history of its role as an enteric pathogen and the current state of knowledge about the organism. Clin. Infect. Dis. 18(Suppl. 4), S265-272.

Bishop, A. L., and Hall, A. (2000). Rho GTPases and their effector proteins. Biochem. J. 348(Pt 2), 241-255.

Borriello, S. P., Davies, H. A., Kamiya, S., Reed, P. J., and Seddon, S. (1990). Virulence factors of Clostridium difficile. Rev. Infect. Dis. 12(Suppl. 2), S185-S191.

Brazier, J. S. (2008). Clostridium difficile: from obscurity to superbug. $\mathrm{Br}$. J. Biomed. Sci. 65, 39-44.

Chaves-Olarte, E., Low, P., Freer, E., Norlin, T., Weidmann, M., Von Burghoffer, B., Noussair, L.,

play an important role in determining what substrates are modified in vivo, so the array of actual targets may be different. Finally, the consequences of modifying different subsets of GTPases for pathogenesis are not known. Clearly, a great deal of work needs to be done to understand the action of these toxins. Elucidating the answers to these questions will help uncover the different roles of TcdA, TcdB, and variant toxins and aid in the development of strategies to prevent their action.

\section{ACKNOWLEDGMENTS}

Rory N. Pruitt and D. Borden Lacy were supported by the Vanderbilt Digestive Disease Research Center P30DK058404, U.S. Public Health Service grant AI095755-01 from the National Institute of Allergy and Infection Diseases, and an Investigator in Pathogenesis of Infectious Disease award from the Burroughs Wellcome Foundation.

Eichel-Streiber, C., and Thelestam, M. (1999). A novel cytotoxin from Clostridium difficile serogroup $\mathrm{F}$ is a functional hybrid between two other large clostridial cytotoxins. J. Biol. Chem. 274, 11046-11052.

Chaves-Olarte, E., Weidmann, M., Eichel-Streiber, C., and Thelestam, M. (1997). Toxins A and B from Clostridium difficile differ with respect to enzymatic potencies, cellular substrate specificities, and surface binding to cultured cells. J. Clin. Invest. 100, 1734-1741.

Chen, X., Katchar, K., Goldsmith, J. D., Nanthakumar, N., Cheknis, A., Gerding, D. N., and Kelly, C. P. (2008). A mouse model of Clostridium difficile-associated disease. Gastroenterology 135, 1984-1992.

Ciesla, W. P. Jr., and Bobak, D. A. (1998). Clostridium difficile toxins A and B are cation-dependent UDPglucose hydrolases with differing catalytic activities. J. Biol. Chem. 273, 16021-16026.

Cohen, L. E., McNeill, C. J., and Wells, R. F. (1973). Clindamycinassociated colitis. JAMA 223, 1379-1380.

Delmee, M., Avesani, V., Delferriere, N., and Burtonboy, G. (1990). Characterization of flagella of Clostridium difficile and their role in serogrouping reactions. J. Clin. Microbiol. 28, 2210-2214.

Donta, S. T., Sullivan, N., and Wilkins, T. D. (1982). Differential effects of Clostridium difficile toxins on tissuecultured cells. J. Clin. Microbiol. 15, 1157-1158.

Egerer, M., Giesemann, T., Jank, T., Satchell, K. J., and Aktories, K. (2007). Auto-catalytic cleavage of Clostridium difficile toxins $\mathrm{A}$ and $\mathrm{B}$ depends on cysteine protease activity. J. Biol. Chem. 282, 25314-25321.
Egerer, M., and Satchell, K. J. (2010). Inositol hexakisphosphate-induced autoprocessing of large bacterial protein toxins. PLoS Pathog. 6:e1000942. doi: 10.1371/journal. ppat. 1000942

Feltis, B. A., Wiesner, S. M., Kim, A. S., Erlandsen, S. L., Lyerly, D. L., Wilkins, T. D., and Wells, C. L. (2000). Clostridium difficile toxins A and $\mathrm{B}$ can alter epithelial permeability and promote bacterial paracellular migration through HT-29 enterocytes. Shock 14, 629-634.

Finney, J. M. T. (1893). Gastroenterostomy for cicatrizing ulcer of the pylorus. Bull. Johns Hopkins Hosp. 4, 53-55.

Geissler, B., Tungekar, R., and Satchell, K. J. (2010). Identification of a conserved membrane localization domain within numerous large bacterial protein toxins. Proc. Natl. Acad. Sci. U.S.A. 107, 5581-5586.

Genisyuerek, S., Papatheodorou, P., Guttenberg, G., Schubert, R., Benz, R., and Aktories, K. (2011). Structural determinants for membrane insertion, pore formation and translocation of Clostridium difficile toxin B. Mol. Microbiol. 79, 1643-1654.

Genth, H., Aktories, K., and Just, I. (1999). Monoglucosylation of RhoA at threonine 37 blocks cytosolmembrane cycling. J. Biol. Chem. 274, 29050-29056.

Genth, H., Dreger, S. C., Huelsenbeck, J., and Just, I. (2008). Clostridium difficile toxins: more than mere inhibitors of Rho proteins. Int. J. Biochem. Cell Biol. 40, 592-597.

Genth, H., Hofmann, F., Selzer, J., Rex, G., Aktories, K., and Just, I. (1996). Difference in protein substrate specificity between hemorrhagic toxin and lethal toxin from Clostridium sordellii. 
Biochem. Biophys. Res. Commun. 229, 370-374.

Geric, B., Carman, R. J., Rupnik, M., Genheimer, C. W., Sambol, S. P., Lyerly, D. M., Gerding, D. N., and Johnson, S. (2006). Binary toxinproducing, large clostridial toxinnegative Clostridium difficile strains are enterotoxic but do not cause disease in hamsters. J. Infect. Dis. 193, 1143-1150.

Giannasca, P. J., and Warny, M. (2004). Active and passive immunization against Clostridium difficile diarrhea and colitis. Vaccine 22, 848-856.

Giesemann, T., Jank, T., Gerhard, R., Maier, E., Just, I., Benz, R., and Aktories, K. (2006). Cholesteroldependent pore formation of Clostridium difficile toxin A. J. Biol. Chem. 281, 10808-10815.

Giry, M., Popoff, M. R., Von EichelStreiber, C., and Boquet, P. (1995). Transient expression of RhoA, -B, and -C GTPases in HeLa cells potentiates resistance to Clostridium difficile toxins $\mathrm{A}$ and $\mathrm{B}$ but not to Clostridium sordellii lethal toxin. Infect. Immun. 63, 4063-4071.

Gouet, P., Courcelle, E., Stuart, D. I., and Metoz, F. (1999). ESPript: analysis of multiple sequence alignments in PostScript. Bioinformatics 15, 305-308.

Greco, A., Ho, J. G., Lin, S. J., Palcic, M. M., Rupnik, M., and Ng, K. K. (2006). Carbohydrate recognition by Clostridium difficile toxin A. Nat. Struct. Mol. Biol. 13, 460-461.

Hall, I. C., and O'Toole, E. (1935). Intestinal flora in new-born infants with a description of a new pathogenic anaerobe, Bacillus difficilis. Am. J. Dis. Child. 49, 390-402.

Herrmann, C., Ahmadian, M. R., Hofmann, F., and Just, I. (1998). Functional consequences of monoglucosylation of $\mathrm{Ha}$-Ras at effector domain amino acid threonine 35. J. Biol. Chem. 273, 16134-16139.

Hippenstiel, S., Schmeck, B., N'Guessan, P. D., Seybold, J., Krull, M., Preissner, K., EichelStreiber, C. V., and Suttorp, N. (2002). Rho protein inactivation induced apoptosis of cultured human endothelial cells. Am. J. Physiol. Lung Cell. Mol. Physiol. 283, L830-L838.

Ho, J. G., Greco, A., Rupnik, M., and Ng, K. K. (2005). Crystal structure of receptor-binding C-terminal repeats from Clostridium difficile toxin A. Proc. Natl. Acad. Sci. U.S.A. 102, 18373-18378.

Hofmann, F., Busch, C., Prepens, U., Just, I., and Aktories, K. (1997).
Localization of the glucosyltransferase activity of Clostridium difficile toxin $\mathrm{B}$ to the $\mathrm{N}$-terminal part of the holotoxin. J. Biol. Chem. 272, 11074-11078.

Huelsenbeck, J., Dreger, S., Gerhard, R., Barth, H., Just, I., and Genth, H. (2007). Difference in the cytotoxic effects of toxin B from Clostridium difficile strain VPI 10463 and toxin B from variant Clostridium difficile strain 1470. Infect. Immun. 75 , 801-809.

Jank, T., Giesemann, T., and Aktories, K. (2007a). Clostridium difficile glucosyltransferase toxin B-essential amino acids for substrate binding. J. Biol. Chem. 282, 35222-35231.

Jank, T., Giesemann, T., and Aktories, K. (2007b). Rho-glucosylating Clostridium difficile toxins $\mathrm{A}$ and B: new insights into structure and function. Glycobiology 17, 15R-22R.

Jiang, Z. D., Dupont, H. L., Garey, K., Price, M., Graham, G., Okhuysen, P., Dao-Tran, T., and Larocco, M. (2006). A common polymorphism in the interleukin 8 gene promoter is associated with Clostridium difficile diarrhea. Am. J. Gastroenterol. 101, 1112-1116.

Johal, S. S., Solomon, K., Dodson, S., Borriello, S. P., and Mahida, Y. R. (2004). Differential effects of varying concentrations of Clostridium difficile toxin $\mathrm{A}$ on epithelial barrier function and expression of cytokines. J. Infect. Dis. 189, 2110-2119.

Just, I., Selzer, J., Wilm, M., Von Eichel-Streiber, C., Mann, M., and Aktories, K. (1995). Glucosylation of Rho proteins by Clostridium difficile toxin B. Nature 375, 500-503.

Kabins, S. A., and Spira, T. J. (1975). Outbreak of clindamycin-associated colitis. Ann. Intern. Med. 83, 830-831.

Karjalainen, T., Waligora-Dupriet, A. J., Cerquetti, M., Spigaglia, P., Maggioni, A., Mauri, P., and Mastrantonio, P. (2001). Molecular and genomic analysis of genes encoding surface-anchored proteins from Clostridium difficile. Infect. Immun. 69, 3442-3446.

Kelly, C. P., and LaMont, J. T. (2008). Clostridium difficile-more difficult than ever. N. Engl. J. Med. 359, 1932-1940.

Kelly, C. P., Pothoulakis, C., and LaMont, J. T. (1994). Clostridium difficile colitis. N. Engl. J. Med. 330, 257-262.

Kim, H., Kokkotou, E., Na, X., Rhee, S. H., Moyer, M. P., Pothoulakis, C., and LaMont, J. T. (2005). Clostridium difficile toxin A-induced colonocyte apoptosis involves p53dependent p21(WAF1/CIP1) induction via p38 mitogen-activated protein kinase. Gastroenterology 129, 1875-1888.

Kreimeyer, I., Euler, F., Marckscheffel, A., Tatge, H., Pich, A., Olling, A., Schwarz, J., Just, I., and Gerhard, R. (2011). Autoproteolytic cleavage mediates cytotoxicity of Clostridium difficile toxin A. Naunyn Schmiedebergs Arch. Pharmacol. 383, 253-262.

Krivan, H. C., Clark, G. F., Smith, D. F., and Wilkins, T. D. (1986). Cell surface binding site for Clostridium difficile enterotoxin: evidence for a glycoconjugate containing the sequence Gal alpha 1-3Gal beta 1-4GlcNAc. Infect. Immun. 53, 573-581.

Kuehne, S. A., Cartman, S. T., Heap, J. T., Kelly, M. L., Cockayne, A., and Minton, N. P. (2010). The role of toxin A and toxin B in Clostridium difficile infection. Nature 467, 711-713.

Kyne, L., Hamel, M. B., Polavaram, R., and Kelly, C. P. (2002). Health care costs and mortality associated with nosocomial diarrhea due to Clostridium difficile. Clin. Infect. Dis. 34, 346-353.

Kyne, L., Warny, M., Qamar, A., and Kelly, C. P. (2001). Association between antibody response to toxin $\mathrm{A}$ and protection against recurrent Clostridium difficile diarrhoea. Lancet 357, 189-193.

Lanis, J. M., Barua, S., and Ballard, J. D. (2010). Variations in TcdB activity and the hypervirulence of emerging strains of Clostridium difficile. PLoS Pathog. 6. doi: 10.1371/journal.ppat. 1001061

Lupardus, P. J., Shen, A., Bogyo, M., and Garcia, K. C. (2008). Small molecule-induced allosteric activation of the Vibrio cholerae RTX cysteine protease domain. Science 322, 265-268.

Lyerly, D. M., Krivan, H. C., and Wilkins, T. D. (1988). Clostridium difficile: its disease and toxins. Clin. Microbiol. Rev. 1, 1-18.

Lyerly, D. M., Lockwood, D. E., Richardson, S. H., and Wilkins, T. D. (1982). Biological activities of toxins $\mathrm{A}$ and $\mathrm{B}$ of Clostridium difficile. Infect. Immun. 35, 1147-1150.

Lyerly, D. M., Saum, K. E., Macdonald, D. K., and Wilkins, T. D. (1985). Effects of Clostridium difficile toxins given intragastrically to animals. Infect. Immun. 47, 349-352.

Lyras, D., O'Connor, J. R., Howarth, P. M., Sambol, S. P., Carter, G. P., Phumoonna, T., Poon, R., Adams, V., Vedantam, G., Johnson, S.,
Gerding, D. N., and Rood, J. I. (2009). Toxin B is essential for virulence of Clostridium difficile. Nature 458, 1176-1179.

Martinez, R. D., and Wilkins, T. D. (1988). Purification and characterization of Clostridium sordellii hemorrhagic toxin and cross-reactivity with Clostridium difficile toxin A (enterotoxin). Infect. Immun. 56, 1215-1221.

Matarrese, P., Falzano, L., Fabbri, A., Gambardella, L., Frank, C., Geny, B., Popoff, M. R., Malorni, W., and Fiorentini, C. (2007). Clostridium difficile toxin B causes apoptosis in epithelial cells by thrilling mitochondria. Involvement of ATP-sensitive mitochondrial potassium channels. J. Biol. Chem. 282, 9029-9041.

McDonald, L. C., Coignard, B., Dubberke, E., Song, X., Horan, T., and Kutty, P. K. (2007). Recommendations for surveillance of Clostridium difficile-associated disease. Infect. Control Hosp. Epidemiol. 28, 140-145.

McDonald, L. C., Killgore, G. E., Thompson, A., Owens, R. C. Jr., Kazakova, S. V., Sambol, S. P., Johnson, S., and Gerding, D. N. (2005). An epidemic, toxin genevariant strain of Clostridium difficile. N. Engl. J. Med. 353, 2433-2441.

Mehlig, M., Moos, M., Braun, V., Kalt, B., Mahony, D. E., and Von EichelStreiber, C. (2001). Variant toxin B and a functional toxin A produced by Clostridium difficile C34. FEMS Microbiol. Lett. 198, 171-176.

Merrigan, M., Venugopal, A., Mallozzi, M., Roxas, B., Viswanathan, V. K., Johnson, S., Gerding, D. N., and Vedantam, G. (2003). Human hypervirulent Clostridium difficile strains exhibit increased sporulation as well as robust toxin production. J. Bacteriol. 192, 4904-4911.

Mesmin, B., Robbe, K., Geny, B., Luton, F., Brandolin, G., Popoff, M. R., and Antonny, B. (2004) A phosphatidylserine-binding site in the cytosolic fragment of Clostridium sordellii lethal toxin facilitates glucosylation of membrane-bound Rac and is required for cytotoxicity. J. Biol. Chem. 279, 49876-49882.

Mitchell, T. J., Ketley, J. M., Haslam, S. C., Stephen, J., Burdon, D. W., Candy, D. C., and Daniel, R. (1986). Effect of toxin A and B of Clostridium difficile on rabbit ileum and colon. Gut 27, 78-85.

Na, X., Kim, H., Moyer, M. P., Pothoulakis, C., and LaMont, J. T. (2008). gp96 is a human colonocyte plasma membrane binding protein 
for Clostridium difficile toxin A. Infect. Immun. 76, 2862-2871.

Nagahama, M., Ohkubo, A., Oda, M., Kobayashi, K., Amimoto, K., Miyamoto, K., and Sakurai, J. (2011). Clostridium perfringens TpeL glycosylates the Rac and Ras subfamily proteins. Infect. Immun. 79, 905-910.

Nottrott, S., Schoentaube, J., Genth, H., Just, I., and Gerhard, R. (2007). Clostridium difficile toxin A-induced apoptosis is p53-independent but depends on glucosylation of Rho GTPases. Apoptosis 12, 1443-1453.

O'Connor, J. R., Lyras, D., Farrow, K. A., Adams, V., Powell, D. R., Hinds, J., Cheung, J. K., and Rood, J. I. (2006). Construction and analysis of chromosomal Clostridium difficile mutants. Mol. Microbiol. 61, 1335-1351.

Olling, A., Goy, S., Hoffmann, F., Tatge, H., Just, I., and Gerhard, R. (2011). The repetitive oligopeptide sequences modulate cytopathic potency but are not crucial for cellular uptake of Clostridium difficile toxin A. PLoS One 6:e17623. doi: 10.1371/journal.pone.0017623

Papatheodorou, P., Zamboglou, C., Genisyuerek, S., Guttenberg, G., and Aktories, K. (2010). Clostridial glucosylating toxins enter cells via clathrin-mediated endocytosis. PLoS One 5:e10673. doi: 10.1371/journal.pone.0010673

Perelle, S., Gibert, M., Bourlioux, P., Corthier, G., and Popoff, M. R. (1997). Production of a complete binary toxin (actin-specific ADPribosyltransferase) by Clostridium difficile CD196. Infect. Immun. 65, 1402-1407.

Pfeifer, G., Schirmer, J., Leemhuis, J., Busch, C., Meyer, D. K., Aktories, K., and Barth, H. (2003). Cellular uptake of Clostridium difficile toxin B. Translocation of the N-terminal catalytic domain into the cytosol of eukaryotic cells. J. Biol. Chem. 278, 44535-44541.

Popoff, M. R., Rubin, E. J., Gill, D. M., and Boquet, P. (1988). Actinspecific ADP-ribosyltransferase produced by a Clostridium difficile strain. Infect. Immun. 56, 2299-2306.

Pothoulakis, C., Gilbert, R. J., Cladaras, C., Castagliuolo, I., Semenza, G., Hitti, Y., Montcrief, J. S., Linevsky, J., Kelly, C. P., Nikulasson, S., Desai, H. P., Wilkins, T. D., and LaMont, J. T. (1996). Rabbit sucrase-isomaltase contains a functional intestinal receptor for Clostridium difficile toxin A. J. Clin. Invest. 98, 641-649.

Prochazkova, K., and Satchell, K. J. (2008). Structure-function analysis of inositol hexakisphosphateinduced autoprocessing of the Vibrio cholerae multifunctional autoprocessing RTX toxin. J. Biol. Chem. 283, 23656-23664.

Prochazkova, K., Shuvalova, L. A., Minasov, G., Voburka, Z., Anderson, W. F., and Satchell, K. J. (2009). Structural and molecular mechanism for autoprocessing of MARTX toxin of Vibrio cholerae at multiple sites. J. Biol. Chem. 284, 26557-26568.

Pruitt, R. N., Chagot, B., Cover, M. Chazin, W. J., Spiller, B., and Lacy, D. B. (2009). Structurefunction analysis of inositol hexakisphosphate-induced autoprocessing in Clostridium difficile toxin A. J. Biol. Chem. 284, 21934-21940.

Pruitt, R. N., Chambers, M. G., Ng, K. K., Ohi, M. D., and Lacy, D. B. (2010). Structural organization of the functional domains of Clostridium difficile toxins A and B. Proc. Natl. Acad. Sci. U.S.A. 107, 13467-13472.

Pruitt, R. N., Chumbler, N. M., Rutherford, S. A., Farrow, M. A., Friedman, D. B., Spiller, B., and Lacy, D. B. (2012). Structural determinants of the Clostridium difficile toxin A glucosyltransferase activity. J. Biol. Chem. (in press).

Puri, A. W., Lupardus, P. J., Deu, E., Albrow, V. E., Garcia, K. C., Bogyo, M., and Shen, A. (2010). Rational design of inhibitors and activity-based probes targeting Clostridium difficile virulence factor TcdB. Chem. Biol. 17, 1201-1211.

Qa'Dan, M., Ramsey, M., Daniel, J., Spyres, L. M., Safiejko-Mroczka, B., Ortiz-Leduc, W., and Ballard, J. D. (2002). Clostridium difficile toxin $\mathrm{B}$ activates dual caspase-dependent and caspase-independent apoptosis in intoxicated cells. Cell. Microbiol. 4, 425-434.

Qa'Dan, M., Spyres, L. M., and Ballard, J. D. (2000). pH-induced conformational changes in Clostridium difficile toxin B. Infect. Immun. 68 2470-2474.

Raaijmakers, J. H., and Bos, J. L. (2009). Specificity in Ras and Rap signaling. J. Biol. Chem. 284, 10995-10999.

Redelings, M. D., Sorvillo, F., and Mascola, L. (2007). Increase in Clostridium difficile-related mortality rates, United States, 1999-2004. Emerg. Infect. Dis. 13, 1417-1419.

Reineke, J., Tenzer, S., Rupnik, M., Koschinski, A., Hasselmayer, O., Schrattenholz, A., Schild, H., and Von Eichel-Streiber, C. (2007). Autocatalytic cleavage of
Clostridium difficile toxin B. Nature 446, 415-419.

Reinert, D. J., Jank, T., Aktories, K., and Schulz, G. E. (2005). Structural basis for the function of Clostridium difficile toxin B. J. Mol. Biol. 351, 973-981.

Riegler, M., Sedivy, R., Pothoulakis, C. Hamilton, G., Zacherl, J., Bischof, G., Cosentini, E., Feil, W., Schiessel, R., LaMont, J. T., and Wenzl, E. (1995). Clostridium difficile toxin B is more potent than toxin A in damaging human colonic epithelium in vitro. J. Clin. Invest. 95, 2004-2011.

Rupnik, M., Grabnar, M., and Geric, B. (2003). Binary toxin producing Clostridium difficile strains. Anaerobe 9, 289-294.

Rupnik, M., Pabst, S., Rupnik, M., Von Eichel-Streiber, C., Urlaub, H., and Soling, H. D. (2005). Characterization of the cleavage site and function of resulting cleavage fragments after limited proteolysis of Clostridium difficile toxin $\mathrm{B}$ (TcdB) by host cells. Microbiology 151, 199-208

Sambol, S. P., Merrigan, M. M., Lyerly, D., Gerding, D. N., and Johnson, S. (2000). Toxin gene analysis of a variant strain of Clostridium difficile that causes human clinical disease. Infect. Immun. 68, 5480-5487.

Savariau-Lacomme, M. P., Lebarbier, C., Karjalainen, T., Collignon, A., and Janoir, C. (2003). Transcription and analysis of polymorphism in a cluster of genes encoding surfaceassociated proteins of Clostridium difficile. J. Bacteriol. 185, 4461-4470.

Savidge, T. C., Pan, W. H., Newman, P., O'Brien, M., Anton, P. M., and Pothoulakis, C. (2003). Clostridium difficile toxin B is an inflammatory enterotoxin in human intestine. Gastroenterology 125, 413-420.

Sebaihia, M., Wren, B. W., Mullany, P., Fairweather, N. F., Minton, N., Stabler, R., Thomson, N. R., Roberts, A. P., Cerdeno-Tarraga, A. M., Wang, H., Holden, M. T., Wright, A., Churcher, C., Quail, M. A., Baker, S., Bason, N., Brooks, K., Chillingworth, T., Cronin, A., Davis, P., Dowd, L., Fraser, A., Feltwell, T., Hance, Z., Holroyd, S., Jagels, K., Moule, S., Mungall, K., Price, C., Rabbinowitsch, E., Sharp, S., Simmonds, M., Stevens, K., Unwin, L., Whithead, S. Dupuy, B., Dougan, G., Barrell, B., and Parkhill, J. (2006). The multidrug-resistant human pathogen Clostridium difficile has a highly mobile, mosaic genome. Nat. Genet. 38, 779-786.

Sehr, P., Joseph, G., Genth, H., Just, I., Pick, E., and Aktories, K. (1998).
Glucosylation and ADP ribosylation of rho proteins: effects on nucleotide binding, GTPase activity, and effector coupling. Biochemistry 37, 5296-5304.

Selzer, J., Hofmann, F., Rex, G., Wilm, M., Mann, M., Just, I., and Aktories, K. (1996). Clostridium novyi alpha-toxin-catalyzed incorporation of GlcNAc into Rho subfamily proteins. J. Biol. Chem. 271, 25173-25177.

Sheahan, K. L., Cordero, C. L., and Satchell, K. J. (2007) Autoprocessing of the Vibrio cholerae RTX toxin by the cysteine protease domain. EMBO J. 26, 2552-2561.

Shen, A. (2010a). Allosteric regulation of protease activity by small molecules. Mol. Biosyst. 6, 1431-1443

Shen, A. (2010b). Autoproteolytic activation of bacterial toxins. Toxins (Basel) 2, 963-977.

Shen, A., Lupardus, P. J., Gersch, M. M., Puri, A. W., Albrow, V. E., Garcia, K. C., and Bogyo, M. (2011). Defining an allosteric circuit in the cysteine protease domain of Clostridium difficile toxins. Nat. Struct. Mol. Biol. 18, 364-371.

Sohn, S., Climo, M., Diekema, D., Fraser, V., Herwaldt, L., Marino, S., Noskin, G., Perl, T., Song, X., Tokars, J., Warren, D., Wong, E., Yokoe, D. S., Zembower, T., and Sepkowitz, K. A. (2005). Varying rates of Clostridium difficileassociated diarrhea at prevention epicenter hospitals. Infect. Control Hosp. Epidemiol. 26, 676-679.

Stabler, R. A., Dawson, L. F., Phua, L. T., and Wren, B. W. (2008). Comparative analysis of BI/NAP1/027 hypervirulent strains reveals novel toxin $\mathrm{B}$-encoding gene (tcdB) sequences. J. Med. Microbiol. 57, 771-775.

Stabler, R. A., Gerding, D. N., Songer, J. G., Drudy, D., Brazier, J. S., Trinh, H. T., Witney, A. A., Hinds, J., and Wren, B. W. (2006). Comparative phylogenomics of Clostridium difficile reveals clade specificity and microevolution of hypervirulent strains. J. Bacteriol. 188, 7297-7305.

Stabler, R. A., He, M., Dawson, L., Martin, M., Valiente, E., Corton, C., Lawley, T. D., Sebaihia, M., Quail, M. A., Rose, G., Gerding, D. N., Gibert, M., Popoff, M. R., Parkhill, J., Dougan, G., and Wren, B. W. (2009). Comparative genome and phenotypic analysis of Clostridium difficile 027 strains provides insight into the evolution of a hypervirulent bacterium. Genome Biol. 10, R102. 
Teneberg, S., Lonnroth, I., Torres Lopez, J. F., Galili, U., Halvarsson, M. O., Angstrom, J., and Karlsson, K. A. (1996). Molecular mimicry in the recognition of glycosphingolipids by Gal alpha $3 \mathrm{Gal}$ beta 4 GlcNAc beta-binding Clostridium difficile toxin $\mathrm{A}$, human natural anti alpha-galactosyl IgG and the monoclonal antibody Gal-13: characterization of a binding-active human glycosphingolipid, nonidentical with the animal receptor. Glycobiology 6, 599-609.

Torres, J. F. (1991). Purification and characterisation of toxin B from a strain of Clostridium difficile that does not produce toxin A. J. Med. Microbiol. 35, 40-44.

Tucker, K. D., Carrig, P. E., and Wilkins, T. D. (1990). Toxin A of Clostridium difficile is a potent cytotoxin. J. Clin. Microbiol. 28, 869-871.

Tucker, K. D., and Wilkins, T. D. (1991). Toxin A of Clostridium difficile binds to the human carbohydrate antigens I, X, and Y. Infect. Immun. 59, 73-78.

Vetter, I. R., Hofmann, F., Wohlgemuth, S., Herrmann, C., and Just, I. (2000). Structural consequences of mono-glucosylation of Ha-Ras by Clostridium sordellii lethal toxin. J. Mol. Biol. 301, 1091-1095.

von Eichel-Streiber, C., LaufenbergFeldmann, R., Sartingen, S., Schulze, J., and Sauerborn, M. (1992a). Comparative sequence analysis of the Clostridium difficile toxins A and B. Mol. Gen. Genet. 233, 260-268.

von Eichel-Streiber, C., Meyer Zu Heringdorf, D., Habermann, E., and Sartingen, S. (1995). Closing in on the toxic domain through analysis of a variant Clostridium difficile cytotoxin B. Mol. Microbiol. 17, 313-321.

von Eichel-Streiber, C., and Sauerborn, M. (1990). Clostridium difficile toxin A carries a C-terminal repetitive structure homologous to the carbohydrate binding region of streptococcal glycosyltransferases. Gene 96, 107-113.

von Eichel-Streiber, C., Sauerborn, M., and Kuramitsu, H. K. (1992b). Evidence for a modular structure of the homologous repetitive Cterminal carbohydrate-binding sites of Clostridium difficile toxins and Streptococcus mutans glucosyltransferases. J. Bacteriol. 174, 6707-6710.

Waligora, A. J., Hennequin, C., Mullany, P., Bourlioux, P. Collignon, A., and Karjalainen, T. (2001). Characterization of a cell surface protein of Clostridium difficile with adhesive properties. Infect. Immun. 69, 2144-2153.

Warny, M., and Kelly, C. P. (1999). Monocytic cell necrosis is mediated by potassium depletion and caspase-like proteases. Am. J. Physiol. 276, C717-724.

Warny, M., Pepin, J., Fang, A., Killgore, G., Thompson, A., Brazier, J., Frost, E., and McDonald, L. C. (2005). Toxin production by an emerging strain of Clostridium difficile associated with outbreaks of severe disease in North America and Europe. Lancet 366, 1079-1084.

Warny, M., Vaerman, J. P., Avesani, V., and Delmee, M. (1994). Human antibody response to Clostridium difficile toxin A in relation to clinical course of infection. Infect. Immun. 62, 384-389.
Ziegler, M. O., Jank, T., Aktories, K., and Schulz, G. E. (2008). Conformational changes and reaction of clostridial glycosylating toxins. J. Mol. Biol. 377, 1346-1356.

Conflict of Interest Statement: The authors declare that the research was conducted in the absence of any commercial or financial relationships that could be construed as a potential conflict of interest.

Received: 24 January 2012; paper pending published: 20 February 2012; accepted: 27 February 2012; published online: 16 March 2012.

Citation: Pruitt RN and Lacy DB (2012) Toward a structural understanding of Clostridium difficile toxins $A$ and $B$. Front. Cell. Inf. Microbio. 2:28. doi: 10.3389/fcimb.2012.00028

Copyright (c) 2012 Pruitt and Lacy. This is an open-access article distributed under the terms of the Creative Commons Attribution Non Commercial License, which permits non-commercial use, distribution, and reproduction in other forums, provided the original authors and source are credited. 